\title{
Financial innovation and economic growth in Bangladesh
}

\author{
Md. Qamruzzaman ${ }^{1,2^{*}}$ iD and Wei Jianguo ${ }^{1}$
}

\author{
* Correspondence: \\ zaman_wut16@yahoo.com \\ ${ }^{1}$ School of Economics, Wuhan \\ University of Technology, Wuhan \\ 430070, China \\ ${ }^{2}$ School of Business and Economics, \\ United International University, \\ Dhaka, Bangladesh
}

\begin{abstract}
Background: This study provides evidence for the financial innovation in the financial system that resulted in the economic growth of Bangladesh from 19802016.

Methods: To capture the influence of financial innovation on economic growth, we estimated the long-run cointegration by applying Autoregressive Distributed Lag (ARDL) bound testing and Granger causality-based Error Correction Model (ECM) to capture the directional association.

Results: The Test of Cointegration satisfied the existence of a long-run association between economic growth and the financial innovation proxies, which were the Domestic Credit to the Private Sector (DCB) as a percentage of the Gross Domestic Product and the Broad-to-Narrow Money (M2/M1) as a percentage of the Gross Domestic Product. Our results showed that in the long run, credit circulation to the private sector and monetary management play important roles in economic growth. We also found that the coefficients of the financial innovation proxy variables were positive and statistically significant both in the short run and long run. We also ran Granger causality tests to investigate the directional effect. This study confirmed the feedback causality between the economic growth and 2 proxies of financial innovation in the short and long run. The gross capital formation and trade openness contribute significantly to explaining the economic growth in Bangladesh.

Conclusion: The government of Bangladesh should encourage financial innovation in the financial system, especially at financial institutions, so that access to financial services can easily provide for equitable development. The government should also encourage financial innovation in the capital market, which will assist in raising longterm capital for investment and expedite overall economic growth.
\end{abstract}

Keywords: Financial innovation, Economic growth, ARDL, Granger causality

JEL classification: $\mathrm{O} 3, \mathrm{O} 4, \mathrm{O} 53$

\section{Background}

The dynamic economic environment is immensely influenced by rapid innovation, especially financial innovation in the financial system, both in terms of number and value (Błach 2011). Financial innovation expands economic activities through promoting financial inclusion, facilitating a financial transaction in international trade, enabling remittance and uplifting financial efficiency, which eventually play a fundamental role in economic growth. Financial innovation, in developing countries like Bangladesh, represents an opportunity

(c) The Author(s). 2017 Open Access This article is distributed under the terms of the Creative Commons Attribution 4.0 International License (http://creativecommons.org/licenses/by/4.0/), which permits unrestricted use, distribution, and reproduction in any medium, provided you give appropriate credit to the original author(s) and the source, provide a link to the Creative Commons license, and indicate if changes were made. 
for financial sector development (Napier 2014; Ndako 2010). It is, because, financial innovation reflect as an agent for exploring Financial development through diversification of financial services (Silve and Plekhanov 2014; Bianchi et al. 2011; Merton 1992), efficient financial intermediation (Johnson and Kwak 2012), technological advancement (Valverde et al., 2007; Michalopoulos et al. 2011), and new channel for efficient resource allocation for productive output (Duasa 2014; Sood and Ranjan 2015), in turn, thus, accelerated sustainable economic growth at large. Financial sector development can cause economic growth, because efficient financial sector mobilized economic resources, assist in capital accumulation (Ahmed 2006) and increase efficiency level in the financial system (Saad 2014a, 2014b; Michael et al. 2015), eventually lead towards economic growth.

Over the decade, Bangladesh experience emergence of diversified financial innovation in the financial system, especially in the banking sector such as emergence of mobile banking, specialized financing options to promote entrepreneurship (i.e., SME refinancing scheme by Bangladesh bank, Aporojita loan for women entrepreneur), internet banking, agent banking, to stimulate financial development process through capital maker development with a view to support capital adequacy to investors, establishment of nonbank financial institutions to support institutional credit for investment. The financial sector of Bangladesh comprises with private commercial banks, insurance companies, leasing companies, specialized financial institutions, such as House Building Finance Corporation, financial markets, and informal financial institutions.

The financial sector of Bangladesh, according to Bangladesh Bank (2017), is dominated banking sector accounting $65 \%$ of total financial assets in the financial sector, followed by nonbank financial institutions $15 \%$ and capital market by $7 \%$ and remaining accounted by informal financial institutions. Financial sector development of Bangladesh not only expediting financial performance but also contributing a noticeable amount in GDP, accounting 12\% having substantial growth rate at 7\% from 2015 to 2016 (BBS, 2017).

Empirical literature about the nexus between financial innovation-growth suggests that there is a strong association between financial innovation and economic growth (see, for example, Bara and Mudxingiri 2016; Bourne and Attzs 2010; Lumpkin 2010; Sekhar 2013). Financial Innovation includes new financial instruments, the creation of new corporate structures, the formation of new financial institutions, the development of new accounting and financial reporting techniques (Laeven et al. 2015; Štreimikiene 2014; Demetriades and Hussein 1996), such development in the financial system is the key to bring financial efficiency with economic growth (Saqib 2015).

Innovation in the financial sector not only accelerated financial development process but also assist in the capital accumulation, a technological innovation which eventually leads sustainable economic growth both short and long run (Chou and Chin 2011; Orji et al. 2015; Mishra 2010).

This study is novel in different aspects. First, Existing empirical studies suggest a few studies been conducted by researcher focusing on nexus of financial development and economic growth in Bangladesh using limited time period data (see, for example, Rahman 2004; Shahbaz et al. 2015), Uddin et al., 2014a, b; Masuduzzaman 2014; Uddin and Chakraborty 2014; Kabir and Hoque 2007; Ali and Hassan 2010; Paul 2014a, 2014b), in this research, we tried to cover long time series data to explore more convincing findings. Second, the Empirical literature shows that no such conclusive research focusing on financial innovation 
impact on economic growth of Bangladesh conducted yet, such research gap encourages us to take the opportunity to explore how and to what extent financial innovation playing a critical role in the development process of Bangladesh. Finally, we are using newly developed ARDL bound testing for investigating long-run association. The paper is structured as follows: theoretical and empirical literature brought in Section 2, Section 3 presents the data and the methodology for the study in details; Research model specification and estimation with details interpretation included in Section 4, and finally Section 5, explain research findings with policy recommendations for future development. The dynamic economic environment is strongly influenced by rapid innovation, especially financial innovation in the financial system (Błach 2011). Financial innovation expands economic activities through promoting financial inclusion, facilitating financial transactions in international trade, enabling remittances, and increasing financial efficiency, which eventually plays fundamental roles in economic growth. Financial innovation in developing countries, such as Bangladesh, represents an opportunity for financial sector development (Napier 2014; Ndako 2010). This opportunity occurs because financial innovation acts as an agent for exploring financial development through the diversification of financial services (Silve and Plekhanov 2014; Bianchi et al. 2011; Merton 1992), efficient financial intermediation (Johnson and Kwak 2012), technological advancement (Valverde et al., 2007; Michalopoulos et al. 2011), and new channels for efficient resource allocation for productive output (Duasa 2014; Sood and Ranjan 2015) that accelerates sustainable economic growth. Financial sector development can cause economic growth because an efficient financial sector can mobilize its economic resources, assist in capital accumulation (Ahmed 2006), and further increase the efficiency level in the financial system (Saad 2014a, 2014b; Michael et al. 2015).

Over the last decade, Bangladesh has experienced the emergence of diversified financial innovations in the financial system, especially in the banking sector, financial innovation bringing changes by offering versatile service introducing mobile banking, specialized financing options to promote entrepreneurship (i.e., the SME refinancing scheme by the Bangladesh bank and Aporojita loans for women entrepreneurs), internet banking, agent banking (which stimulates the financial development process through capital making developments to support the capital adequacy for investors), and the establishment of non-bank financial institutions to support institutional credit for investment. The financial sector of Bangladesh comprises private commercial banks, insurance companies, leasing companies, specialized financial institutions (such as the House Building Finance Corporation), financial markets, and informal financial institutions.

According to Bangladesh Bank (2017), the financial sector in Bangladesh is dominated by banking, which accounts for $65 \%$ of the total financial assets in the financial sector, followed by non-bank financial institutions (15\%) and the capital market (7\%); the remaining part is comprised of informal financial institutions. The development of the financial sector in Bangladesh not only expedites financial performance but it also significantly contributes to the GDP (12\%); this sector experienced substantial growth (7\%) from 2015 to 2016 (BBS, 2017).

Empirical studies about the nexus between financial innovation and growth suggest that there is a strong association between them (Bara and Mudxingiri 2016; Bourne and Attzs 2010; Lumpkin 2010; Sekhar 2013). Financial innovation includes new financial instruments, the creation of new corporate structures, the formation of new financial institutions, and the development of new accounting and financial reporting 
techniques (Laeven et al. 2015; Štreimikiene 2014; Demetriades and Hussein 1996). Such developments in the financial system are key to bringing financial efficiency with economic growth (Saqib 2015). Innovation in the financial sector not only accelerates the financial development process, but it also assists in capital accumulation, a technological innovation which eventually leads to sustainable economic growth in both the short and long run (Chou and Chin 2011; Orji et al. 2015; Mishra 2010). This study is novel in several aspects. First, existing empirical studies suggest that little research has been conducted on the nexus of financial development and economic growth in Bangladesh using a limited time period (Rahman 2004; Shahbaz et al. 2015; Uddin et al., 2014a, b; Masuduzzaman 2014; Uddin and Chakraborty 2014; Kabir and Hoque 2007; Ali and Hassan 2010; Paul 2014a, 2014b). In this research, we examined the data from a long time period to reveal more significant results. Second, a literature search revealed that there is no conclusive research focusing on the impact of financial innovation on the economic growth of Bangladesh. This research gap encouraged us to explore how and to what extent financial innovation plays a critical role in the development process of Bangladesh. Finally, we used the newly developed ARDL bound testing to investigate the long-run association. This paper is structured as follows: the theoretical and empirical literature is discussed in section 2. Section 3 presents the data and methodology for the study in detail. The research model specifications and estimations with a detailed interpretation are included in section 4. In section 5, we explain our research findings with policy recommendations for future development.

\section{Theoretical and empirical literature review}

\section{Theoretical literature}

Innovation is an obvious driver of economic growth because it introduces new ideas, instruments, and solutions for the existing problems. Most importantly, it changes business competitiveness and creates more value for enterprises. Innovation can take place in the real sector and financial sector of the economy. It can be categorized as all of the scientific, technological, financial, and commercial activity necessary to create, implement and develop new financial markets with improved financial assets (OECD 2004). Innovation not only considers the creation of a new thing but also acts as the panacea for prolonged economic problems (Kotsemir and Abroskin 2013). Schumpeter (1912) indicated that innovation can take place in the form of a new product, process, market, raw material, a method of distribution, or organizational structure.

The traditional economic view of innovation growth states that financial innovation improves the quality of financial products and services (Schrieder and Heidhues 1995; McGuire and Conroy 2013), expedites the financial development process (Ozcan 2008), improves capital accumulation and allocation processes (Uddin et al., 2014a, b; Allen 2011), and increases the level of efficiency in financial institutions (Shaughnessy, 2015). The efficiency of financial institutions, moreover, has an impact on financial development through better payment mechanisms that expedite both domestic and international trade (Sabandi and Noviani 2015).

Institutional innovation, like other types of innovation, in the financial system, expedites the financial process with improvements, such as internet banking and mobile banking services (Raffaelli and Glynn 2013; Hargrave and Ven 2006), Microfinance 
institutions, NGOs, and hybrid organizational forms (Battilana and Dorado 2010). These innovations improve the economy by including a greater number of people in the mainstream economic development process (Epstein 1992; Siddiqui and Ahmed 2009; Glaeser et al. 2004).

\section{Empirical literature review}

The existing literature suggests that the development of the financial sector has a strong association with economic growth (Asghar and Hussain 2014; Bwirea and Musiime 2015; Comin and Nanda 2014; Duasa 2014; Hye and Islam 2013; Jedidia et al. 2014; Khoutem et al., 2014; Kyophilavong et al. 2016; Masuduzzaman 2014; Mhadhbi 2014; Ndlovu 2013; Rana and Barua 2015; Saad 2014a, 2014b; Sunde 2013; Uddin et al., 2014a, b). This association exists because an efficient financial system allows for the effective mobilization of economic resources with higher productivity. The idea of financial innovation is not a new one, but over the last decade, its speed has created some challenges that impact financial development, including structural changes in the financial sector, the reshaping of financial services, and the introduction of new financial assets in the financial markets. Financial innovation introduces and popularizes new financial instruments, institutions, and technologies to the financial system (Sood and Ranjan 2015). Schumpeter (1911) emphasized the importance of well-functioning financial intermediaries in innovation and economic growth. The interactions of innovations in the financial sector create economic growth.

Financial innovation is an integral part of economic activity; for example, financial innovation has resulted in structural changes in the financial system through the improvement in financial services and modified payment systems (Boot and Marinc 2010; Michalopoulos et al. 2011), new products and features for existing financial products (Sekhar 2013; Simiyu et al. 2014), and new financial institutions and financial markets (Odularu and Okunrinboye 2008; Simiyu et al. 2014). It has also brought about changes in government regulations and shifted social perceptions (Mwinzi 2014; Wachter 2006; Chou and Chin 2011).

Financial development can take place with various financial innovations, such as the improvement of the capital market and the banking sector. A well-functioning capital market and banking sector contribute to economic development (Ndako 2010; Handa and Khan (2008)) through capital formation, the efficient allocation of resources, and by establishing a bridge between surplus units and deficit units. In the opinion of Wadud (2009), Adusei (2013), and Cavenaile et al. (2011), well-developed banks and the capital market both play a significant role in sustainable equitable development by allowing productive investment (Mhadhbi 2014; Orji et al. 2015; Ilhan, 2008; Ansong et al. 2011; Bakang 2016). These, in turn, accelerate economic growth (Ang 2008; Duasa 2014), but the impact of financial development is subject to economic conditions (Adusei 2013). Uddin et al. (2012) showed that financial development through the improvements in the banking sector can cause economic development and also assist in poverty reduction. Developing the financial sector allows people access to more institutional credit for investment (Uddin and Chakraborty 2014). According to Rana and Barua (2015), credit from financial institutions is yet to have an immense influence on promoting the overall economic development in South Asian countries. The development of the financial market is considered to be a channel of efficient economic 
resource mobilization (Kerr and Nanda 2014). Financial markets intensify the process of capital accumulation. A well-functioning capital market plays a driving role in sustainable economic development through the adoption of financial innovation in the economy (Levine 1997).

An efficient financial system is a prerequisite for a modern economy (Wachter 2006), which includes financial markets, institutions, instruments, and regulations (Mannah-Blankson and Belnye 2004). It offers value-added financial services and payment mechanisms (Bilyk 2006), (Ajide 2015; Nagayasu 2012). Such financial facilities in the financial system expedite economic growth by creating financial opportunities (Beck et al. 2012; Chou 2007). Efficient financial intermediation enhances economic activity by providing better financial support in trade and commerce by lowering the investment risk through diversification (Djoumessi 2009; Shittu 2012; Cheng and Degryse 2014). A robust and efficient financial system promotes growth by the reallocation of economic resources in the economy in an effective and efficient manner.

An efficient financial system is the outcome of continuous financial innovation (Blair 2011), which allows for the emergence of various financial institutions, especially banks, with improved financial services and more credit facilities, liquid cash, and financial instruments, which leads to economic growth (Levine 1997; Jedidia et al. 2014).

\section{Methods}

\section{Variable and sources}

Our analysis used the annual time series data for the period 1980-2016. The data were collected and transformed from 3 sources: the World Development Indicators published by the World Bank (World Bank 2017), the World Economic Outlook published by the IMF (World Economic Outlook 2017), and the Bangladesh Economic Review published by the Ministry of Finance (MOF 2016). The research variables are positively defined in Table 1. The statistical analysis package Eviews 9.5 was used for the data analysis.

We selected the real GDP per capita as the economic growth indicator, which is widely used by researchers (Bara et al. 2016; Bara and Mudxingiri 2016; Ajide 2015; Cavenaile et al. 2011; Ndlovu 2013; Sabandi and Noviani 2015; Mwinzi 2014). If any country experienced an increasing trend in its GDP per capita over the selected time period, we assumed that that economy was growing.

Financial innovation in the economy brings about changes through the introduction of new financial instruments, institutions, services, and reporting (Laeven et al. 2015). The impact of financial innovation on the economy is diversified and no single variable can be considered as an appropriate indicator for measuring its significance in the economy. We selected 2 Proxy indicators to measure financial innovation. The first proxy for financial innovation is the Domestic Credit to the Private Sector (DCB), which refers to the ratio of the number of credit facilities to the private sector for investment in the form of securities, loan, and other accounts receivable. Growth economic theory predicts that capital adequacy will positively influence economic growth, and so we assigned this variable a positive sign for its coefficient. Using the approach found in Bakang (2016), the second proxy for financial innovation was defined as the 
Table 1 Variable Definitions with Their Expected Signs

\begin{tabular}{lll}
\hline Variables & Definition & Expected sign \\
\hline GDPPC & $\begin{array}{l}\text { Par Capital Economic Growth Rate: The Percentage } \\
\text { change in per capita GDP, used as our indicator of } \\
\text { economic growth. }\end{array}$ & \\
INF & Inflation Rate: Measured in percentage change in the CPI. & Negative \\
DCB & $\begin{array}{l}\text { Domestic Credit to Private Sector: Measures as total financial } \\
\text { support to private sector by financial institution through } \\
\text { trade credit, loans and other account receivables as a } \\
\text { percentage of GDP }\end{array}$ & Positive \\
& $\begin{array}{l}\text { Trade Openness: Measured as total trade (exports plus imports) } \\
\text { as a percentage of GDP, used to gauge how open the economy is. }\end{array}$ & Positive \\
TO & $\begin{array}{l}\text { Gross Fixed Capital Formation: Measures net physical assets } \\
\text { increase in the economy as a percentage of GDP }\end{array}$ & Positive \\
M2/M1 & $\begin{array}{l}\text { Broad- to- Narrow Money: Measures the demand for real } \\
\text { cash balance as well as interest and income elasticities of } \\
\text { money demand as a percentage of GDP. }\end{array}$ & Positive/Negative \\
& $\begin{array}{l}\text { Government Final Consumption Expenditure: Measured as } \\
\text { a percentage of GDP to capture the degree of government } \\
\text { involvement in the economy. }\end{array}$ & \\
\hline
\end{tabular}

Note 1: All monetary measures are in real US dollars

Note 2: All the variables above are defined in the World Development Indicator and World Economic Outlook published by World Bank and IMF

Note 3: We use the natural log of those variables in our estimation

Table 2 Descriptive Statistics for the variables

\begin{tabular}{|c|c|c|c|c|c|c|c|}
\hline Variables & $\operatorname{lnCPI}$ & $\operatorname{lnM} 2 \mathrm{M} 1$ & InGDPPC & $\operatorname{lnGEXP}$ & $\operatorname{lnGCF}$ & $\ln D C B$ & $\operatorname{lnTO}$ \\
\hline \multicolumn{8}{|c|}{ Part 1. Summary Statistics } \\
\hline Mean & 1.72 & 0.31 & 1.21 & 1.61 & 3.16 & 3.64 & 3.46 \\
\hline Median & 1.82 & 0.30 & 1.18 & 1.62 & 3.20 & 3.78 & 3.37 \\
\hline Maximum & 2.37 & 0.55 & 1.75 & 1.69 & 3.36 & 4.12 & 3.87 \\
\hline Minimum & 0.69 & 0.20 & 0.073 & 1.41 & 2.82 & 3.01 & 2.93 \\
\hline Std. Dev. & 0.47 & 0.07 & 0.42 & 0.06 & 0.16 & 0.39 & 0.27 \\
\hline Skewness & -0.85 & 1.69 & -0.77 & -1.38 & -0.73 & -0.36 & -0.12 \\
\hline Kurtosis & 2.72 & 5.48 & 3.19 & 5.26 & 2.33 & 1.55 & 1.97 \\
\hline Jarque-Bera & 3.10 & 18.45 & 2.53 & 13.35 & 2.71 & 2.72 & 1.15 \\
\hline Probability & 0.21 & 0.089 & 0.28 & 0.012 & 0.25 & 0.25 & 0.56 \\
\hline
\end{tabular}

Part 2. Correlation Matrix

\begin{tabular}{|c|c|c|c|c|c|c|c|}
\hline $\ln C P I$ & 1 & & & & & & \\
\hline InM2 M1 & 0.18 & 1 & & & & & \\
\hline InGDPPC & 0.41 & 0.32 & 1 & & & & \\
\hline InGEXP & 0.31 & 0.29 & 0.75 & 1 & & & \\
\hline $\operatorname{lnGCF}$ & 0.32 & 0.59 & 0.81 & 0.85 & 1 & & \\
\hline $\ln D C B$ & 0.44 & 0.77 & 0.80 & 0.72 & 0.25 & 1 & \\
\hline InTO & 0.42 & 0.47 & 0.85 & 0.71 & 0.31 & 0.91 & 1 \\
\hline
\end{tabular}

Note: 1. CPI: Consumer Price Index, M2/M1: Broad-to-Narrow Money, GEXP: Government Expenditure, GCF: Gross Capital Formation, DCB: Domestic Credit to Private Sector, TO: Trade Openness and GDPPC: Gross Domestic Product Per Capita. Variables are positively defined (see Table 1)

Note 2: Values reported here are the natural logs of the variables. We use natural log forms in our estimation 
Broad-to-Narrow Money (M2/M1) (Laeven et al. 2015; Bara and Mudxingiri 2016; Bara et al. 2016; Ansong et al. 2011).

The other macroeconomic variables we used were the Gross Capital Formation (GCF) and Trade Openness (TO), which were both expected to have a positive coefficient, implying a positive impact on economic growth. The Government Expenditure (GEXP) and Consumer Price Index (CPI) were given negative coefficients, implying their negative effects. Variables were converted into their natural logs for further estimation. Table 2 shows the descriptive statistics and correlations among the variables. Figure 1 exhibits a graphical representation of the natural log form of the research variables.

\section{Augmented Dickey-Fuller (ADF) test}

It has to be observed from an empirical study that time series data have a complicated dynamic structure which is not fully captured by simple AR (1) model. Said and Dickey (1984) augment the basic AR unit root model to ARMA(p,q) with the inclusion of unknown order which is now well known as augmented Dickey-Fuller (ADF) test. Augmented Dickey-fuller test considering $\mathrm{H}_{0}$ : series $x_{t}$ is I (1) against I (0) by assumption of data have dynamic structure.

In order to testify variables stationary and order of integration, we use Augmented Dicky-Fuller test (1981). The test to be conducted by the consideration of $n^{\text {th }}$ order difference of the seven variables. The test ADF use autoregressive (AR) process.

$$
x_{t}=D_{t} \gamma_{1}+\gamma_{2} x_{t-1}+\sum_{i=1}^{n} \pi_{i} \Delta x_{t-i}+\varepsilon_{t}
$$

Where, $D_{t}$ is a vector of deterministic term (constant, trend etc.), $\mathrm{n}$ for lagged difference term, $\Delta x_{t-i}$ term for ARMA structure of the error and $\varepsilon_{t}$ is for white nose (error term).

\section{Phillips-Perron unit root tests}

Finding the unit root using the Phillips -Perron (PP) test rather than the ADF has become popular because the PP test is capable of dealing with serial correlations and Heteroskedasticity in the error. For example, where the ADF tests use a parametric autoregression to approximate the ARMA structure of the errors in the test regression,

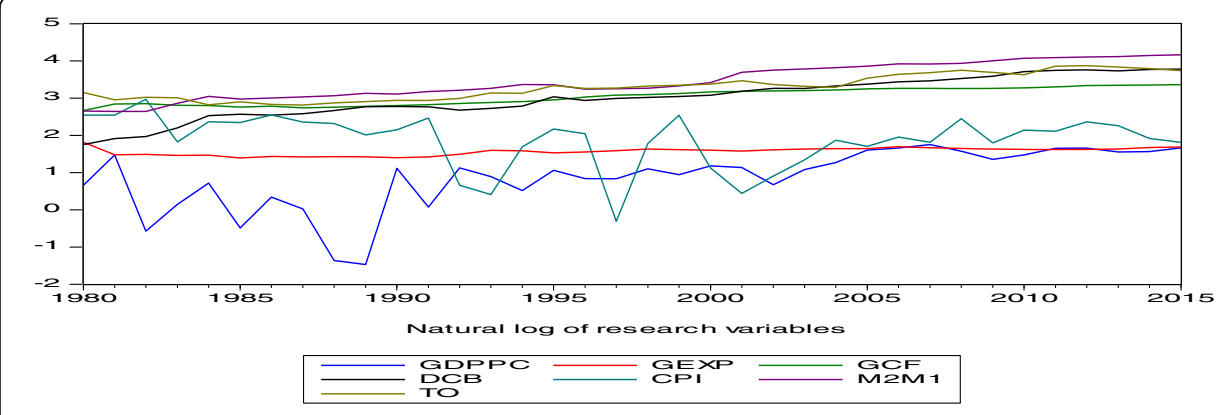

Fig. 1 Natural log of research variables 
the PP test ignore any serial correlation in the test regression. The test regression for the PP test is:

$$
x_{t}=D_{t} \gamma_{1}+\gamma_{2} x_{t-1}+\varepsilon_{t}
$$

Where $\varepsilon_{t}$ is I (0) and may be Heteroskedastic. The PP test rectify any serial correlation and Heteroskedasticity in error term.

\section{The extended Aghion, Howitt, and Mayer - Foulkes (AHM) model}

Our study used an extended Aghion, Howitt, and Mayer-Foulkes (AHM) model developed by Laeven et al. (2015) and subsequently used by Bara and Mudxingiri (2016). Both of these studies tested models to find the impact of financial innovation on endogenous growth; they used the assumption that "the economy without financial innovation will stagnate, irrespective of the initial level of financial development". The AHM model was developed based on the Schumpeterian growth model, where entrepreneurs earn a profit by introducing better products and services.

$$
g-g_{1}=b_{0}+b_{1} F+b_{2}\left(y-y_{1}\right)+b_{3} F\left(y-y_{1}\right)+b_{4} X+u
$$

To test the model, Laeven et al. (2015), Bara and Mudxingiri (2016), and Bara et al. (2016) extended the AHM model to incorporate financial innovation with financial development. All of the researchers emphasized financial innovation. In their models, they assumed that the financial development that occurs in any period is the impact of previous financial innovations. Bara et al. (2016) derived the following model from the AHM framework:

$$
g-g_{1}=b_{0}+b_{1} F_{t}+b_{2}\left(y_{t}-y_{t 1}\right)+b_{3} F_{t}\left(y_{i}-y_{1 t}\right)+b_{4} X_{t}+b_{5} f_{t}+b_{6} f_{t}\left(y_{t}-y_{1 t}\right)+u_{t}
$$

The dynamic regression model to be estimated in this study as follows:

$$
\overbrace{\text { GGDPPC }}^{Y}=[\overbrace{G E X P_{t}, C P I_{t}, T O_{t}}^{X}+\overbrace{G G D P P C_{t-1}}^{y_{t-1}}+\overbrace{G C F_{t}}^{F}+\overbrace{D C B_{t}, \frac{M 2}{M 1} t}^{f i}]
$$

Where $\mathrm{Y}$ is the growth of GDP per Capital, $\mathrm{X}$ are control variables, $\mathrm{F}$ is financial development and fi are financial innovation. The linear form of eq. (5) is followed;

$$
\begin{aligned}
\ln G D P P C=\beta_{0} & +\beta_{1} \ln G E X P_{t}+\beta_{2} \ln C P I_{t}+\beta_{3} \ln T O_{t}+\beta_{4} \ln G D P P C_{t} \\
& +\beta_{5} \ln G C F_{t}+\beta_{6} \ln D C B_{t}+\beta_{7} \ln \frac{M 2}{M 1_{t}}+\varepsilon_{t}
\end{aligned}
$$

Where $\ln$ is for natural logarithm, GDPPC is the Growth Rate of GDP per Capital, GEXP is Government Expenditure, CPI is Consumer Price Index, TO is Trade Openness, GCF is Gross Capital Formation, DCB is Domestic Credit to Private Sector and M2/M1 is the ration Broad-to-Narrow Money. For capturing speed of adjustment towards equilibrium from any shock in variables, we formulated the following error correction model (ECM) to estimate: 


$$
\begin{gathered}
{\left[\begin{array}{c}
\Delta \ln (\text { gdppc })_{t} \\
\Delta \ln (\text { gexp })_{t} \\
\Delta \ln (c p i)_{t} \\
\Delta \ln (g c f)_{t} \\
\Delta \ln (t o)_{t} \\
\Delta \ln (d c b)_{t} \\
\Delta \ln \left(\frac{m 2}{m 1}\right)_{t}
\end{array}\right]=\left[\begin{array}{c}
\alpha_{1} \\
\alpha_{2} \\
\alpha_{3} \\
\alpha_{4} \\
\alpha_{5} \\
\alpha_{6} \\
\alpha_{7}
\end{array}\right]+\sum_{k=1}^{q}(1-L)\left[\begin{array}{l}
\beta_{11 k} \beta_{12 k} \beta_{13 k} \beta_{14 k} \beta_{15 k} \beta_{16 k} \beta_{17 k} \\
\beta_{21 k} \beta_{22 k} \beta_{23 k} \beta_{24 k} \beta_{25 k} \beta_{26 k} \beta_{27 k} \\
\beta_{31 k} \beta_{32 k} \beta_{33 k} \beta_{34 k} \beta_{35 k} \beta_{36 k} \beta_{37 k} \\
\beta_{41 k} \beta_{42 k} \beta_{43 k} \beta_{44 k} \beta_{45 k} \beta_{46 k} \beta_{57 k} \\
\beta_{51 k} \beta_{52 k} \beta_{53 k} \beta_{54 k} \beta_{55 k} \beta_{56 k} \beta_{57 k} \\
\beta_{61 k} \beta_{62 k} \beta_{63 k} \beta_{64 k} \beta_{65 k} \beta_{66 k} \beta_{67 k} \\
\beta_{71 k} \beta_{72 k} \beta_{73 k} \beta_{74 k} \beta_{75 k} \beta_{76 k} \beta_{77 k}
\end{array}\right]} \\
\left.\begin{array}{c}
\Delta \ln (g d p p c)_{t-k} \\
\Delta \ln (g e x p)_{t-k} \\
\Delta \ln (c p i)_{t-k} \\
\Delta \ln (g c f)_{t-k} \\
\Delta \ln (t o)_{t-k} \\
\Delta \ln (d c b)_{t-k} \\
\gamma_{1} E C T_{t-1} \\
\gamma_{2} E C T_{t-1} \\
\gamma_{4} E C T_{t-1} \\
\gamma_{5} E C T_{t-1} \\
\gamma_{6} E C T_{t-1} \\
\gamma_{7} E C T_{t-1}
\end{array}\right]+\left[\begin{array}{l}
\varepsilon_{1 t} \\
\varepsilon_{2 t} \\
\varepsilon_{3 t} \\
\varepsilon_{4 t} \\
\varepsilon_{5 t} \\
\varepsilon_{6 t} \\
\varepsilon_{7 t}
\end{array}\right]
\end{gathered}
$$

All the variables are positively defined earlier, except $\Delta$ represent change and $E C T_{t-1}$ is the error term lagged in one period and $\varepsilon$ represents white noise. The coefficient of first difference of the variables show short run causality and coefficient of $E C T_{t-1}$ shows long run causality.

\section{The autoregressive distributed lag (ARDL) model}

Several cointegration methods are available for use, including the residual basis Engle and Granger (1987) test and the maximum-likelihood-based Johansen (1991; 1995) and Johansen-Juselius (1990) tests. Since there are limitations to these models, researchers have turned to the Ordinary-Least-Square- (OLS) based Autoregressive Distribution Lag (ARDL) approach. Its advantage over other cointegration methods is its flexibility for using a set of variables that are integrated in a different order (Pesaran et al. 2001a, 2001b). Moreover, a dynamic Error Correction Model (ECM) can be derived from the ARDL through using the linear transformation (Banerjee et al., 1993).

This study used the ARDL model due to its advantages over other cointegration models. First, the Autoregressive Distribution Lag Model is superior because it can be used regardless of sample size (which can be small or infinite) and consists of 30 to 80 observations (Ghatak and Siddiki 2001). Second, this approach is more suitable when variables 
are integrated in a different order, such as when some variables are I (0) and some variables are I (1). Third, modeling the ARDL with the appropriate lags corrects for both the serial correlation and indigeneity problem (Pesaran et al. 2001a, 2001b). Fourth, the ARDL model can be used to simultaneously estimate the long-run and short-run cointegration relations and provide an unbiased estimation (Pesaran et al. 2001a, 2001b). A simplified ARDL model (see, Paul 2014a, 2014b) for the variables X, Y, and Z can be expressed as:

$$
\begin{aligned}
\Delta y_{t}= & \varnothing_{1}+\gamma_{1} y_{t-1}+\gamma_{2} x_{t-1}+\gamma_{3} z_{t-1}+\theta_{1} \sum_{i=1}^{n} \Delta y_{t-1}+\theta_{2} \sum_{i=1}^{n} \Delta x_{t-1} \\
& +\theta_{3} \sum_{i=1}^{n} \Delta z_{t-1}+\varepsilon_{1 t}
\end{aligned}
$$

Where $\gamma_{1}, \gamma_{2}, \gamma_{3}$ are long run coefficients whose sum is equivalent to the error correct term at VECM model and $\theta_{1}, \theta_{2} \theta_{3}$ represents short run coefficients. The generalized ARDL model for assessing financial innovation impact on economic growth of Bangladesh is as follows;

$$
\begin{aligned}
\Delta \ln (G D P P C)_{t}= & C_{0}+\beta_{1} \Delta \ln (G E X P)_{t-1}+\beta_{2} \Delta \ln (C P I)_{t-1}+\beta_{3} \Delta \ln (T O)_{t-1} \\
& +\beta_{4} \Delta \ln (G D P P C)_{t-1}+\beta_{5} \Delta \ln (G C F)_{t-1}+\beta_{6} \Delta \log (D C B)_{t-1} \\
& +\beta_{7} \Delta \log \left(\frac{M 2}{M 1}\right)_{t-1}+\lambda_{0} \log (G D P P C)_{t-1}+\lambda_{1} \log (G E X P)_{t} \\
& +\lambda_{2} \log (C P I)_{t}+\lambda_{3} \log (T O)_{t}+\lambda_{4} \log (G C F)_{t}+\lambda_{5} \log (D C B)_{t} \\
& +\lambda_{6} \log \left(\frac{M 2}{M 1}\right)_{t}+\varepsilon_{t}
\end{aligned}
$$

Where $\Delta$ indicates differencing of variables, while $\varepsilon_{t}$ is the error term (white noise), and (t1 ) is for lagged period, $\lambda_{0}$ to $\lambda_{6}$ is long run coefficient. To capture long run cointegration among variables, we formulate following ARDL models considering each variable as dependent variable to estimate best fitted model for further analysis (shown in matrix form).

$$
\left.\left[\begin{array}{c}
\Delta \ln (g d p p c)_{t} \\
\Delta \ln (g e x p)_{t} \\
\Delta \ln (c p i)_{t} \\
\Delta \ln (g c f)_{t} \\
\Delta \ln (t o)_{t} \\
\Delta \ln (d c b)_{t} \\
\Delta \ln \left(\frac{m 2}{m 1}\right)_{t}
\end{array}\right]=\left[\begin{array}{c}
\delta_{1} \\
\delta_{2} \\
\delta_{3} \\
\delta_{4} \\
\delta_{5} \\
\delta_{6} \\
\delta_{7}
\end{array}\right]+\left[\begin{array}{l}
\ln (g d p p c)_{t-1} \\
\ln (g \exp )_{t-1} \\
\ln (c p i)_{t-1} \\
\ln (g c f)_{t-1} \\
\ln (t o)_{t-1} \\
\ln (d c b)_{t-1} \\
\ln \left(\frac{m 2}{m 1}\right)_{t-1}
\end{array}\right]\left[\begin{array}{l}
\theta_{11} \theta_{12} \theta_{13} \theta_{14} \theta_{15} \theta_{16} \theta_{17} \\
\theta_{21} \theta_{22} \theta_{23} \theta_{24} \theta_{25} \theta_{26} \theta_{27} \\
\theta_{31} \theta_{32} \theta_{33} \theta_{34} \theta_{35} \theta_{36} \theta_{37} \\
\theta_{41} \theta_{42} \theta_{43} \theta_{44} \theta_{45} \theta_{46} \theta_{47} \\
\theta_{51} \theta_{52} \theta_{53} \theta_{54} \theta_{55} \theta_{56} \theta_{57} \\
\theta_{61} \theta_{62} \theta_{63} \theta_{64} \theta_{65} \theta_{66} \theta_{67} \\
\theta_{71} \theta_{72} \theta_{73} \theta_{74} \theta_{75} \theta_{76} \theta_{77}
\end{array}\right]\right]+\sum_{s=1}^{q}
$$

$$
\left[\begin{array}{l}
\mu_{11 s} \mu_{12 s} \mu_{13 s} \mu_{14 s} \mu_{15 s} \mu_{16 s} \mu_{17 s} \\
\mu_{21 s} \mu_{22 s} \mu_{23 s} \mu_{24 s} \mu_{25 s} \mu_{26 s} \mu_{27 s} \\
\mu_{31 s} \mu_{32 s} \mu_{33 s} \mu_{34 s} \mu_{35 s} \mu_{36 s} \mu_{37 s} \\
\mu_{41 s} \mu_{42 s} \mu_{43 s} \mu_{44 s} \mu_{45 s} \mu_{46 s} \mu_{47 s} \\
\mu_{51 s} \mu_{52 s} \mu_{53 s} \mu_{54 s} \mu_{55 s} \mu_{56 s} \mu_{57 s} \\
\mu_{61 s} \mu_{62 s} \mu_{63 s} \mu_{64 s} \mu_{65 s} \mu_{66 s} \mu_{67 s} \\
\mu_{71 s} \mu_{72 s} \mu_{73 s} \mu_{74 s} \mu_{75 s} \mu_{76 s} \mu_{77 s}
\end{array}\right]\left[\begin{array}{l}
\Delta \ln (g d p p c)_{t-s} \\
\Delta \ln (g \exp )_{t-s} \\
\Delta \ln (c p i)_{t-s} \\
\Delta \ln (g c f)_{t-s} \\
\Delta \ln (t o)_{t-s} \\
\Delta \ln (d c b)_{t-s} \\
\Delta \ln \left(\frac{m 2}{m 1}\right)_{t-s}
\end{array}\right]+\left[\begin{array}{l}
\varepsilon_{1 t} \\
\varepsilon_{2 t} \\
\varepsilon_{3 t} \\
\varepsilon_{4 t} \\
\varepsilon_{5 t} \\
\varepsilon_{6 t} \\
\varepsilon_{7 t}
\end{array}\right]
$$


The bound test for examining the long run association among variables can be conducted using $\mathrm{F}$ tests. The approximate Critical values for $\mathrm{F}$ test can be obtained from Narayan 2004; Pesaran et al. 2001a, 2001b. The null hypothesis of no cointegration among variables in equation (8) is $\theta_{11}, \ldots . \theta_{77}=0$; and alternative hypothesis is $\theta_{11}$, ..... $\theta_{77} \neq 0$.

The F-statistics have non-normal distributions for the following reasons (Narayan 2004): the ARDL model variables' order of integration was either me (0) or me (1), the number of regressions used in the estimation varied, and the ARDL model contained trends or/and intercepts. The decision concerning the cointegration existence is based on the critical values and F-statistics. If the F-statistics are greater than the critical value of the upper bound I (1), then we can make a conclusive inference about the existence of the cointegration among the variables.

Once, the long-run association established, next 2 steps need to be executed to estimate long run and short run coefficients of the proposed ARDL models. The long-run ARDL ( $m, n, q, t, v, x, p)$ equilibrium model is as follows:

$$
\begin{aligned}
\operatorname{lngdppc}_{t}= & \sigma_{0}+\sum_{k=1}^{m} \beta_{k} \ln (g d p p c)_{t-k}+\sum_{k=0}^{n} \gamma_{k} \ln (D C B)_{t-k}+\sum_{k=0}^{q} \delta_{k} \ln (C P I)_{t-k} \\
& +\sum_{k=0}^{t} \mu_{k} \ln (T O)_{t-k}+\sum_{k=0}^{v} \pi_{k} \ln (D C F)_{t-k}+\sum_{k=0}^{x} \rho_{k} \ln (G E X P)_{t-k} \\
& +\sum_{k=0}^{P} \rho_{k} \ln (M 2 / M 1)_{t-k}+\varepsilon_{t}
\end{aligned}
$$

The legs length of ARDL model to be estimated using Akaike Information Criterion (AIC). Using time series data for the study, Pesaran et al. (2001a, 2001b) proposed maximum lag length is 1 . The short-run elasticities can be derived by formulating error correction model as follows:

$$
\begin{aligned}
\Delta \ln (G D P P C)_{t}= & \sigma_{0}+\sum_{k=1}^{n} \beta_{k} \Delta \ln (G D P P C)_{t-k}+\sum_{k=0}^{n} \gamma_{k} \Delta \ln (D C B)_{t-k} \\
& +\sum_{k=0}^{n} \delta_{k} \Delta \ln (C P I)_{t-k}+\sum_{k=0}^{n} \mu_{k} \Delta \ln (T O)_{t-k} \\
& +\sum_{k=0}^{n} \pi_{k} \Delta \ln (D C F)_{t-k}+\sum_{k=0}^{n} \rho_{k} \Delta \ln (G E X P)_{t-k} \\
& +\sum_{k=0}^{P} \sigma_{k} \Delta \ln (M 2 / M 1)_{t-k}+\phi E C T_{t-1}+\omega_{t}
\end{aligned}
$$

Where error correction term can be express as:

$$
\begin{gathered}
E C T_{t}=\ln (G D P P C)_{t}-\sigma_{0}-\sum_{k=1}^{m} \beta_{k} \ln (G D P P C)_{t-k}-\sum_{k=0}^{n} \gamma_{k} \ln (D C B)_{t-k}-\sum_{k=0}^{q} \delta_{k} \ln (C P I)_{t-k} \\
-\sum_{k=0}^{t} \mu_{k} \ln (T O)_{t-k}-\sum_{k=0}^{v} \pi_{k} \ln (D C F)_{t-k}-\sum_{k=0}^{x} \rho_{k} \ln (G E X P)_{t-k}-\sum_{k=0}^{T} \sigma_{\mathrm{k}} \Delta \ln (M 2 / M 1)_{t-k}
\end{gathered}
$$

We expected the coefficient of ECT to be negative and statistically significant to explain the speed of the adjustment towards the equilibrium. To ascertain the goodness of the fit of the ARDL model, the diagnostic and stability tests were also conducted through serial 
correlations, functional forms, normality, and Heteroskedasticity associated with the model. The stability tests of the regression coefficients were also performed.

\section{Results and Discussion}

\section{Stationary test}

Table 3 shows the stationary test outcomes of the research variables with the ADF and PP methods. The table shows that the variables were not integrated in the same order. The variable $\ln (\mathrm{CPI})$ is stationary at level I (0), whereas $\ln (\mathrm{M} 1 / \mathrm{M} 2), \ln (\mathrm{DCB}), \ln$ (TO), ln (GDPPC), ln (GEXP), and ln (GCF) become stationary after the first difference I (1). However, no variables are integrated at I (2); it is the necessary condition of the nature of such variables that suggest applying the ARDL for further analysis.

Table 4 shows the optimal length is 1 out of the maximum of 4 lags, which was selected after considering 5 different criteria. A further analysis found that the optimal lag length is 1 .

\section{ARDL bounds tests for cointegration}

Long-run cointegration was investigated through ARDL bound testing with a null hypothesis and no cointegration; the test results are exhibited in Table 2. Model 1 and 2 refer to financial innovation using 2 proxy variables (M2/M1 and DCB). Model 3 refers to the financial development using the gross capital formation as a proxy. During the bound testing of these 3 models, we ran each model by considering each variable as the dependent variable to investigate the long-run cointegration. Fifteen models were tested. Table 5 shows that only 3 models (1a, 2a, and 3a) show a high F-value compared to the critical value at a $1 \%$ level of significance given by Pesaran et al. (2001a, 2001b) and Narayan (2004). It indicates that there is conclusive evidence in favor of a long-run association between financial innovation, financial development, and economic growth. These findings are in line with those in the literature (Ajide 2015; Boot and Marinc 2010; Chou and Chin 2011; Duasa 2014; Merton 1992; Mosongo et al. 2013) (Table 5).

Table 3 Unit Root Test

\begin{tabular}{|c|c|c|c|c|c|}
\hline \multirow[t]{2}{*}{ Variables } & \multicolumn{2}{|c|}{ Augmented Dickey-Fuller test statistic } & \multicolumn{2}{|c|}{ Phillips-Perron test statistic } & \multirow{2}{*}{$\begin{array}{l}\text { Integration } \\
\text { (I) }\end{array}$} \\
\hline & At level & 1st diff & At level & 1st diff & \\
\hline $\ln (\mathrm{M} 2 / \mathrm{M} 1$ & $-1.78(0.11)$ & $-4.78(0.01)$ & $-0.10(0.22)^{* *}$ & $-2.10(0.02)^{* *}$ & I (1) \\
\hline $\ln \mathrm{nCB}$ & $-0.63(0.84)$ & $-4.51(0.00)^{* *}$ & $-0.59(0.85)$ & $-4.57(0.00)^{* *}$ & I (1) \\
\hline $\operatorname{lnTO}$ & $-1.36(0.58)$ & $-4.68(0.00)^{* *}$ & $-1.32(0.60)$ & $-4.88(0.00)^{*}$ & I (1) \\
\hline InGDPPC & $-1.99(0.28)$ & $-5.95(0.00)^{*}$ & $-1.95(0.30)$ & $-6.29(0.00)^{*}$ & I (1) \\
\hline InGEXP & $-3.33(0.24)$ & $-3.85(0.00)^{*}$ & $-3.38(0.21)$ & $-5.14(0.00)^{*}$ & I (1) \\
\hline $\operatorname{lnGCF}$ & $-2.36(0.16)$ & $-3.14(0.03)^{* *}$ & $-2.19(0.21)$ & $-3.04(0.04)^{* *}$ & I (1) \\
\hline $\operatorname{lnCPI}$ & $-3.51(0.01)^{* *}$ & & & $-3.49(0.01)^{* *}$ & I (0) \\
\hline
\end{tabular}

Note: 1. CPI: Consumer Price Index, M2/M1: Broad-to-Narrow Money, GEXP: Government Expenditure, GCF: Gross Capital Formation, DCB: Domestic Credit to Private Sector, TO: Trade Openness and GDPPC: Gross Domestic Product Per Capita. Variables are positively defined (see Table 1)

Note 2: Values reported () in brackets are the associated probability of coefficients

Note $3:\left(^{*}\right) \&\left({ }^{* *}\right)$ significance at $5 \%$ and $1 \%$, respectively

Note 4: Values reported here are the natural logs of the variables. We use natural log forms in our estimation 
Table 4 Lag length Selection

\begin{tabular}{|c|c|c|c|c|c|}
\hline Lag & $L R$ & FPE & $\mathrm{AIC}$ & SC & $\mathrm{HQ}$ \\
\hline 0 & 198.33 & 20.36 & 18.86 & 19.21 & 18.91 \\
\hline 1 & $171.30^{\mathrm{a}}$ & $15.78^{\mathrm{a}}$ & $12.24^{\mathrm{a}}$ & $14.99^{\mathrm{a}}$ & $12.97^{\mathrm{a}}$ \\
\hline 2 & 185.74 & 17.33 & 13.22 & 16.98 & 17.99 \\
\hline 3 & 188.78 & 19.857 & 14.75 & 20.49 & 19.84 \\
\hline 4 & 201.35 & 21.18 & 17.98 & 22.12 & 20.95 \\
\hline
\end{tabular}

\section{Long-run and short-run coefficients estimation}

Once the long-run cointegration was confirmed by the bound testing when economic growth was the dependent variable (Table 6), we proceeded to estimate the long elasticities by using the ADRL model's long equation. The estimated long-run coefficients ( $p$-value) of the 3 models are shown in Table 6.

\section{Narrow-to-broad money (M2/M1) as a proxy for financial innovation}

The financial innovation proxy M2/M1 had a positive coefficient and statistically significant. It implies that over the long run, the financial innovation related to the increasing money supply has a positive impact on the economic growth of Bangladesh. This outcome is in line with the findings from the literature (Bara and Mudxingiri

Table 5 Bound Testing Results

\begin{tabular}{|c|c|c|c|c|c|c|}
\hline \multirow{2}{*}{\multicolumn{3}{|c|}{ Model $-1: \frac{M_{2}}{M_{1}}$ is the proxy as Financial Innovation }} & \multirow{2}{*}{\multicolumn{2}{|c|}{ F-value }} & \multirow{2}{*}{\multicolumn{2}{|c|}{ Cointegration }} \\
\hline & & & & & & \\
\hline \multirow{2}{*}{\multicolumn{3}{|c|}{ 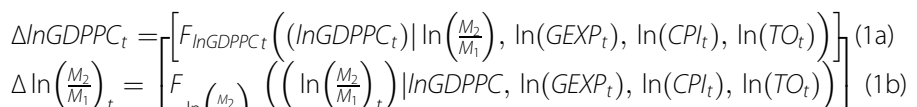 }} & \multicolumn{2}{|l|}{17.75} & \multicolumn{2}{|c|}{ Present } \\
\hline & & & \multicolumn{2}{|l|}{1.89} & \multicolumn{2}{|c|}{ Absent } \\
\hline \multicolumn{3}{|c|}{ 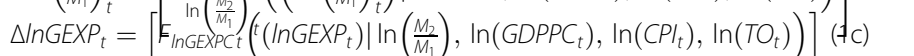 } & \multicolumn{2}{|l|}{3.23} & \multicolumn{2}{|c|}{ Absent } \\
\hline \multicolumn{3}{|c|}{$\Delta /\left.n C P\right|_{t}=\left[F_{\ln C P \mid t}\left(\left(\left.\operatorname{InCPI}\right|_{t}\right) \mid \ln \left(\frac{M_{2}}{M_{1}}\right), \ln \left(G D P P C_{t}\right), \ln \left(G E X P_{t}\right), \ln \left(T O_{t}\right)\right)\right](1 \mathrm{~d})$} & \multicolumn{2}{|l|}{2.56} & \multicolumn{2}{|c|}{ Absent } \\
\hline \multicolumn{3}{|c|}{$\Delta \operatorname{lnTO} O_{t}=\left[F_{\ln T O t}\left(\left(\ln T O_{t}\right) \mid \ln \left(\frac{M_{2}}{M_{1}}\right), \ln \left(G D P P C_{t}\right), \ln \left(C P I_{t}\right), \ln \left(G E X P_{t}\right)\right)\right](1 \mathrm{e})$} & \multicolumn{2}{|l|}{3.29} & \multicolumn{2}{|c|}{ Absent } \\
\hline \multicolumn{7}{|c|}{ Model - 2: DCB is the proxy as Financial Innovation } \\
\hline \multicolumn{3}{|c|}{ 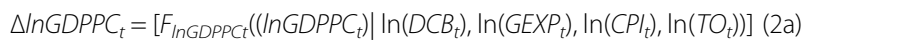 } & \multicolumn{2}{|l|}{9.78} & \multicolumn{2}{|c|}{ Present } \\
\hline \multicolumn{3}{|c|}{ 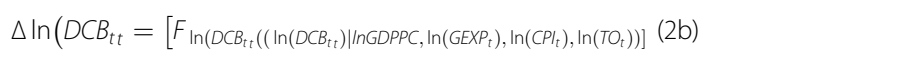 } & \multicolumn{2}{|l|}{2.98} & \multicolumn{2}{|c|}{ Absent } \\
\hline \multicolumn{3}{|c|}{ 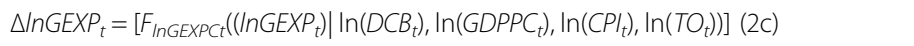 } & \multicolumn{2}{|l|}{3.19} & \multicolumn{2}{|c|}{ Absent } \\
\hline \multicolumn{3}{|c|}{ 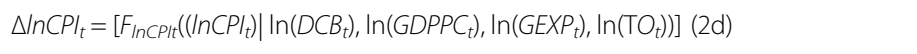 } & \multicolumn{2}{|l|}{3.49} & \multicolumn{2}{|c|}{ Absent } \\
\hline \multicolumn{3}{|c|}{$\Delta \operatorname{lnTO_{t}}=\left[F_{\ln T O t}\left(\left(\ln T O_{t}\right) \mid \ln \left(D C B_{t}\right), \ln \left(G D P P C_{t}\right), \ln \left(C P I_{t}\right), \ln \left(G E X P_{t}\right)\right)\right](2 \mathrm{e})$} & \multicolumn{2}{|l|}{3.53} & \multicolumn{2}{|c|}{ Absent } \\
\hline \multicolumn{7}{|c|}{ Model - 3: GCF is the proxy as Financial Development } \\
\hline$\triangle I n G D P P C_{t}=\left[F_{\text {InGDPPCt }}((\operatorname{lnGDPf}\right.$ & $r t, i n$ & $\left.\left.n\left(C P I_{t}\right), \ln \left(T O_{t}\right)\right)\right](3 a)$ & 11.29 & & Presen & \\
\hline 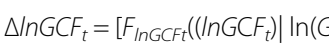 & $D P P C_{t}$ & $\left.\ln \left(T O_{t}\right)\right] 3(b)$ & 3.10 & & Absent & \\
\hline$\Delta / n G E X P_{t}=\left[F_{\operatorname{lnGEXPCt}}\left(\left(\operatorname{lnGEXP_{t})}\right)\right.\right.$ & JL & $\left.\left.\left(P I_{t}\right), \ln \left(T O_{t}\right)\right)\right](3 \mathrm{c})$ & 2.74 & & Absent & \\
\hline$\Delta /\left.n C P\right|_{t}=\left[F_{\ln C P I t}\left(\left(\mid n C P I_{t}\right) \mid \ln (G C P\right.\right.$ & $P\left(C_{t}\right), I$ & $\left.\left.\ln \left(T O_{t}\right)\right)\right](3 d)$ & 2.89 & & Absent & \\
\hline$\Delta l n T O_{t}=\left[F_{\text {InTOt }}\left(\left(I n T O_{t}\right)\right) \mid \ln (G C F\right.$ & $(t, 1)$ & $\left.\left[E X P_{t}\right)\right](3 e)$ & 2.07 & & Absent & \\
\hline & & $10 \%$ & $5 \%$ & & $1 \%$ & \\
\hline Pesaran et al. (2001a, 2001b) & K & I (0) & I (0) & I (1) & I (0) & I (1) \\
\hline & 4 & 2.45 & 2.86 & 4.01 & 4.28 & 5.84 \\
\hline Narayan (2005) & 4 & 2.20 & 2.56 & 3.49 & 3.29 & 4.37 \\
\hline intercept and $\mathrm{r}$ & & & & & & \\
\hline
\end{tabular}


Table 6 Estimated Long-Run coefficient for the period 1980-2016

\begin{tabular}{llll}
\hline & Model -1 AlC criteria & Model - 2 AlC criteria & Model - 3 AIC criteria \\
\hline C & $7.83(0.02)^{*}$ & $5.69(0.02)^{*}$ & $0.024(0.03)^{*}$ \\
InDCB & - & $0.09(0.003)^{* * *}$ & \\
InM2/M1 & $0.65(0.03)^{*}$ & - & $0.086(0.007)^{* *}$ \\
InGEXP & $0.28(0.001)^{* *}$ & $0.49(0.01)^{* *}$ & $0.43(0.001)^{* *}$ \\
in GCF & & & $-.059(0.01)^{* *}$ \\
InCPI & $-0.081(0.002)^{* *}$ & $-0.01(0.0021)^{*}$ & $0.054(0.004)^{* *}$ \\
InTO & $0.086(0.001)^{* *}$ & $0.091(0.04)^{*}$ & \\
\hline
\end{tabular}

Note: 1. CPI: Consumer Price Index, M2/M1: Broad-to-Narrow Money, GEXP: Government Expenditure, GCF: Gross Capital Formation, DCB: Domestic Credit to Private Sector, TO: Trade Openness and GDPPC: Gross Domestic Product Per Capita. Variables are positively defined (see Table 1)

Note 2: Values reported () in brackets are the associated probability of coefficients

Note $3:\left(^{*}\right) \&\left({ }^{*}\right)$ significance at $5 \%$ and $1 \%$, respectively

Note 4: Values reported here are the natural logs of the variables. We use natural log forms in our estimation

2016; Ogunmuyiwa and Ekone 2010). It is apparent (Table 6) that a 1\% increase in the money supply will increase economic growth by $0.65 \%$. The growth economic theory suggests that increasing the money supply in the economy expedites the aggregated production level with a reduction in the cost of production. The availability of the money supply increases the credit option in the economy with a lower cost of capital. The relationship between the M2/M1 and GDPPC ensures that financial innovation in the financial system of Bangladesh will have a positive impact on its long-run sustainable economic growth. The government, therefore, should formulate innovationfriendly financial policies to encourage financial innovation.

\section{Domestic credit from private sector (DCB) as a proxy for financial innovation}

Model -2 is developed by considering another proxy variable of financial innovation is Domestic Credit to Private Sector (DCB). We found (Table 6) that DCB had a positive impact on economic growth and the coefficient is statistically significant. The empirical studies of Ndlovu (2013), Tyavambiza and Nyangara (2015), and Michalopoulos et al. (2011) support these findings; however, Bara and Mudxingiri (2016) found a positive association between them that was insignificant. The Economic Development theory explains that an efficient and well-functioning financial sector accelerates the capital accumulation process, which leads to economic development (Kyophilavong et al. 2016). The development of the banking sector in Bangladesh has played a significant role in economic development through financial improvements. In order to accelerate financial development, financial innovation should be encouraged to obtain the maximum benefit from it. In the long run, both indicators of financial innovation show their positive association with significance. In order to boost the economic growth of Bangladesh, policymakers should assist in the process of financial innovation. Financial innovation promotes financial development, which leads to long-term sustainable economic growth (Habibullah and Yoke-Kee 2007).

The Error Correction Term (ETC) represents the speed of adjustment towards the equilibrium over the long run. According to Pahlavani et al. (2005), a stable model and long-run association can be identified by considering the coefficient for the ECT and associated p-value. Table 5 shows the ARDL short-run dynamics with the ECT coefficient. It is apparent that all 3 of the models satisfy the criteria proposed by Pahlavani et al. (2005) about the ECT(-1) (i.e., it has a negative sign and is statistically significant). 
The coefficients of the ECT $(-1)$ for the 3 models are $-0.49,-0.57$, and -0.55 , respectively. These values indicate that about $49 \%$ for Model - 1, 57\% for Model - 2, and 55\% for Model - 3 of the disequilibrium of the previous year's shock can be adjusted in the current year.

The financial innovation indicators (Table 7) in all of the models have a positive impact over the long run, but the coefficients are not statistically significant. In Model - 1, the M2/M1 shows a positive impact on the short-run economic growth that is statistically significant. The positive impact of the M2/M1 is supported by the economic theory that states the additional money supply will increase aggregated production in the short run, but the actual effects will only be observed in the long run. In other words, the money supply in the economy can be translated into economic growth for Bangladesh, but its impact is significant over the long run, although the short-run impact is positive, but not significant. It is also apparent that another indicator of financial innovation (DCB) has a positive impact and is statistically significant. It indicates that the development of the banking sector plays a positive role in the economic development process.

\section{The VECM granger causality analysis}

We used VECM analysis in order to investigate causality; the results are shown in Table 6. This table shows the coefficients of the short-run and long-run tests. The lagged ECT $(-1)$ represents the long-run causality in the model; for the long-run causality, the existence error term should be negative and statistically significant. It is obvious (Table 8) that

Table 7 Short-run Dynamics Estimates

\begin{tabular}{|c|c|c|c|}
\hline & Model - 1 AlC criteria & Model - 2 AIC criteria & Model - 3 AIC criteria \\
\hline$\overline{\mathrm{ECT}}(-1)$ & $-0.49(0.01)^{* *}$ & $-0.57(0.005)^{* *}$ & $-0.55(0.003)^{* *}$ \\
\hline C & $-0.086(0.86)$ & $-0.94(0.048)^{*}$ & $0.54(0.005)^{* *}$ \\
\hline$\triangle \operatorname{lnGDPPC}(-1)$ & $0.75(0.01)^{* *}$ & $0.56(0.002)^{* * *}$ & $0.72(0.004)^{* * *}$ \\
\hline$\Delta \ln M 2 M 1(-1)$ & $0.54(0.01)^{* *}$ & & \\
\hline$\triangle \operatorname{lnDCB}$ & & $0.10(0.002)^{* *}$ & \\
\hline$\triangle \operatorname{lnGEXP}$ & $0.081(0.03)^{*}$ & $0.25(0.03)^{*}$ & $0.08(0.01)^{* *}$ \\
\hline$\triangle \mathrm{lnGCF}$ & & & $0.80(0.03)^{*}$ \\
\hline$\Delta \operatorname{lnCPI}(-1)$ & $-0.04(0.6155)$ & $-0.061(0.42)$ & $-0.06(0.38)$ \\
\hline$\Delta \operatorname{lnTO}(-1)$ & $0.09(0.018)^{* *}$ & $0.16(0.03)^{*}$ & $0.11(0.009)^{* *}$ \\
\hline \multicolumn{4}{|l|}{ Diagnostic Test } \\
\hline$R^{2}$ & 0.71 & 0.86 & 0.97 \\
\hline$F_{\text {statistics }}^{2}$ & $1.51(0.023)$ & $10.37(0.00)$ & $3.80(0.00)$ \\
\hline$x_{\text {Autocorrelation }}^{2}$ & $1.81(0.40)$ & $0.47(0.49)$ & $1.81(0.43)$ \\
\hline$x_{\text {Normality }}^{2}$ & $1.61(0.44)$ & $0.28(0.87)$ & $1.61(0.45)$ \\
\hline$x_{\text {Heteroskedasticity }}^{2}$ & $6.78(0.45)$ & $3.46(0.94)$ & $6.78(0.47)$ \\
\hline$x_{\text {RESET }}^{2}$ & $0.82(0.27)$ & $0.02(0.87)$ & $3.65(0.24)$ \\
\hline
\end{tabular}

Note: 1. CPI: Consumer Price Index, M2/M1: Broad-to-Narrow Money, GEXP: Government Expenditure, GCF: Gross Capital Formation, DCB: Domestic Credit to Private Sector, TO: Trade Openness and GDPPC: Gross Domestic Product Per Capita. Variables are positively defined (see Table 1)

Note 2: Values reported () in brackets are the associated probability of coefficients

Note $3:\left(^{*}\right) \&\left(^{* *}\right)$ significance at $5 \%$ and $1 \%$, respectively

Note 4: Values reported here are the natural logs of the variables. We use natural log forms in our estimation Note 5: $\Delta$ denotes the first order difference operator 
Table 8 VECM Granger Causality Test Results

\begin{tabular}{|c|c|c|c|c|c|c|}
\hline \multirow[b]{2}{*}{ Dependent Variables } & \multicolumn{5}{|c|}{ Short-run Causality } & \multirow{2}{*}{$\begin{array}{l}\text { Lagged Error } \\
\text { Correction } \\
\text { Coefficient }\end{array}$} \\
\hline & \multicolumn{5}{|c|}{ Independent Variables } & \\
\hline \multicolumn{7}{|c|}{ Model 1: VECM with (GDPPC, GEXP, CPI, M2/M1, TO) } \\
\hline & $\triangle \mathrm{lnGDPPC}$ & $\Delta \ln G E X P$ & $\Delta \mathrm{ln} C P \mathrm{I}$ & $\Delta \ln M 2 / M 1$ & $\Delta \mathrm{ln} T \mathrm{~T}$ & $\mathrm{ECT}(-1)$ \\
\hline$\triangle \ln$ GDPPC & & $0.16(0.001)^{* *}$ & $0.49(0.75)$ & $0.016(0.002)^{* *}$ & $0.16(0.012)^{*}$ & $-0.75(0.002)^{* *}$ \\
\hline$\triangle \ln G E X P$ & $8.41(0.043)^{*}$ & & $5.71(0.174)$ & $2.840 .041)^{*}$ & $0.64(0.221)$ & $-0.05(0.00)^{* *}$ \\
\hline$\Delta \mathrm{ln} C P \mathrm{I}$ & $5.63(0.121)$ & $7.46(0.122)$ & & $0.008(0.001)^{* *}$ & $5.81(0.015)^{*}$ & $0.04(0.152)$ \\
\hline$\Delta \ln M 2 M 1$ & $0.66(0.021)^{*}$ & $1.25(0.041)^{*}$ & $2.61(0.002)^{* *}$ & & $0.49(0.004)^{* *}$ & $-0.48(0.002)^{* *}$ \\
\hline$\Delta \ln T O$ & $1.06(0.004)^{* *}$ & $3.12(0.001)^{* *}$ & $0.28(0.012)^{* *}$ & $0.006(0.001)^{* *}$ & & $-0.33(0.005)^{* *}$ \\
\hline \multicolumn{7}{|c|}{ Model 2: VECM with (GDPPC, GEXP, CPI, DCB, TO) } \\
\hline & $\triangle \mathrm{InGDPPC}$ & $\Delta \ln G E X P$ & $\Delta \mathrm{ln} C P \mathrm{I}$ & $\Delta \mathrm{ln} T \mathrm{TO}$ & $\triangle \ln D C B$ & $\mathrm{ECT}(-1)$ \\
\hline$\triangle \ln$ GDPPC & & $0.32(0.003)^{* *}$ & $0.67(0.170)$ & $0.24(0.024)^{*}$ & $0.37(0.009)^{* *}$ & $-.025(0.002)^{* *}$ \\
\hline$\Delta \ln G E X P$ & $2.01(0.012)^{*}$ & & $2.23(0.154)$ & $2.37(0.017)^{*}$ & $2.74(0.001)^{* *}$ & $-0.54(0.045)^{*}$ \\
\hline$\Delta \mathrm{ln} C \mathrm{CP}$ & $4.76(0.118)$ & $5.34(0.024)^{*}$ & & $5.99(0.185)$ & $1.51(0.003)^{* *}$ & $0.12(0.41)$ \\
\hline$\Delta \mathrm{ln} T \mathrm{TO}$ & $0.42(0.019)^{*}$ & $1.39(0.002)^{* *}$ & $1.24(0.127)$ & & $0.07(0.321)$ & $-0.02(0.006)^{* *}$ \\
\hline$\triangle \ln D C B$ & $6.09(0.021)^{*}$ & $4.19(0.005)^{* *}$ & $7.21(0.003)^{* *}$ & $4.64(0.42)$ & & $-0.10(0.012)^{*}$ \\
\hline \multicolumn{7}{|c|}{ Model 3: VECM with (GDPPC, GEXP, CPI, GCF, TO) } \\
\hline & $\triangle \mathrm{lnGDPPC}$ & $\Delta \ln G E X P$ & $\Delta \mathrm{ln} C \mathrm{CP}$ & $\Delta \ln T O$ & $\triangle \ln$ GCF & $\mathrm{ECT}(-1)$ \\
\hline$\triangle \ln$ GDPPC & & $1.48(0.017)^{*}$ & $3.37(0.178)$ & $0.15(0.001)^{* *}$ & $0.22(0.003)^{* *}$ & $-0.37(.025)^{* *}$ \\
\hline$\triangle \ln$ GEXP & $4.44(0.12)$ & & $3.58(0.002)^{* *}$ & $0.24(0.021)^{*}$ & $2.29(0.012)^{*}$ & $-0.12(0.035)^{*}$ \\
\hline$\Delta \mathrm{ln} C \mathrm{CPI}$ & $6.15(0.029)^{*}$ & $3.23(0.017)^{*}$ & & $2.27(0.005)^{* *}$ & $3.40(0.001)^{* *}$ & $-0.33(0.159)$ \\
\hline$\Delta \mathrm{ln} T \mathrm{TO}$ & $6.36(0.004)^{* *}$ & $9.93(0.001)^{* *}$ & $7.55(0.002)^{* *}$ & & $0.35(0.042)$ & $-0.11(001)^{* *}$ \\
\hline$\triangle \ln G C F$ & $0.01(0.001)^{* *}$ & $5.56(0.012)^{*}$ & $1.02(0.145)$ & $0.57(0.002)^{* *}$ & & $-0.14(0.002)^{* *}$ \\
\hline
\end{tabular}

Note: 1. CPI: Consumer Price Index, M2/M1: Broad-to-Narrow Money, GEXP: Government Expenditure, GCF: Gross Capital Formation, DCB: Domestic Credit to Private Sector, TO: Trade Openness and GDPPC: Gross Domestic Product Per Capita. Variables are positively defined (see Table 1)

Note 2: Values reported () in brackets are the associated probability of coefficients

Note $3:\left(^{*}\right) \&\left(^{* *}\right)$ significance at $5 \%$ and $1 \%$, respectively

Note 4: Values reported here are the natural logs of the variables. We use natural log forms in our estimation

Note 5: $\Delta$ denotes the first order difference operator

Note 6: VECM is the Vector Error Correction Model and ECT Stands for Error Correction Term

the lagged ECT $(-1)$ coefficient is negative and statistically significant for those models where the dependent variables are $\operatorname{lnGDPPC}$, $\ln \mathrm{M} 2 / \mathrm{M} 1$, and $\operatorname{lnDCB}$. This result implies that a feedback causality exists in long-run economic growth and financial innovation $[\operatorname{lnGDPPC}<==>\ln \mathrm{M} 2 / \mathrm{M} 1]$, which is supported by Bara and Mudxingiri (2016) and Mannah-Blankson and Belnye (2004), study also explored that feedback hypothesis is also prevail between $[\ln G D P P C<==>\ln D C B]$, which is in line with results in the literature (Rana and Barua 2015). On the other hand, we also observed that financial development and economic growth support the feedback hypothesis over the long run [lnGDPPC $<==$ $>\operatorname{lnGCF}]$, which is in line with results in the literature (Singh 2008).

In short-run, we also found that feedback hypothesis exist between $[\mathrm{M} 2 / \mathrm{M} 1<==>$ GDPPC] and [DCB $<==>$ GDPPC], which captures the short-run causality of the 3 models, it is implying that in short-run additional money supply in the economy and credit flow to private sector development can cause economic growth and simultaneously any adjustment in GPD also influence on Money supply and credit flow in the economy.. This analysis revealed a similar short-run causality between financial development and economic growth, as well. 


\section{Model stability analysis}

In addition, having structural economic changes in Bangladesh, it might be macroeconomic series subject to one or more structural breaks. Thus, we go for estimating model stability to ensuring acceptability of both long run and short run coefficient of the study. For stability test of econometric models, significant number of researchers rely on cumulative sum and cumulative sum squares (see, for example, Nyasha and Odhiambo 2016; Omoniyi and Olawale 2015; Shrestha and Chowdhury 2005, Alimi 2014; Pesaran et al. 2001a, 2001b; Narayan and Smyth 2005) which is proposed by Borensztein et al. 1998).

Figures 2a, 3 and $4 \mathrm{~b}$ report cumulative sum of recursive residual (CUSUM) and the cumulative sum of the square of recursive residuals (CUSUMQ) of all three proposed model of the study, it is revealed that test line falls within the $5 \%$ significant level critical boundary. This implies the stability of estimated parameters of a proposed model of the period of 1980 to 2016, indicating there are no systematic changes identified. These findings also consistent with existing literature (see, for example, Motsatsi 2016; Owusu 2016; Ozturk 2008; Pan and Mishra 2016; Ozturk and Acaravci 2010; Narayan 2005).

\section{Conclusion and recommendations}

Financial innovation is not a new phenomenon in the financial system, over the past decade, modern economy experience financial reforms, structural changes with innovative financial institutions, and financial assets as a means of financial development (Michalopoulos et al. 2011). Financial innovation constitutes the introduction and promotion of the financial system by offering better and improved financial products, services, and new processes that establish interactions with customers and assist in the creation of a new financial structure for financial development, which eventually expedites a sustainable economic development program (Nagayasu 2012; Saqib 2015). This

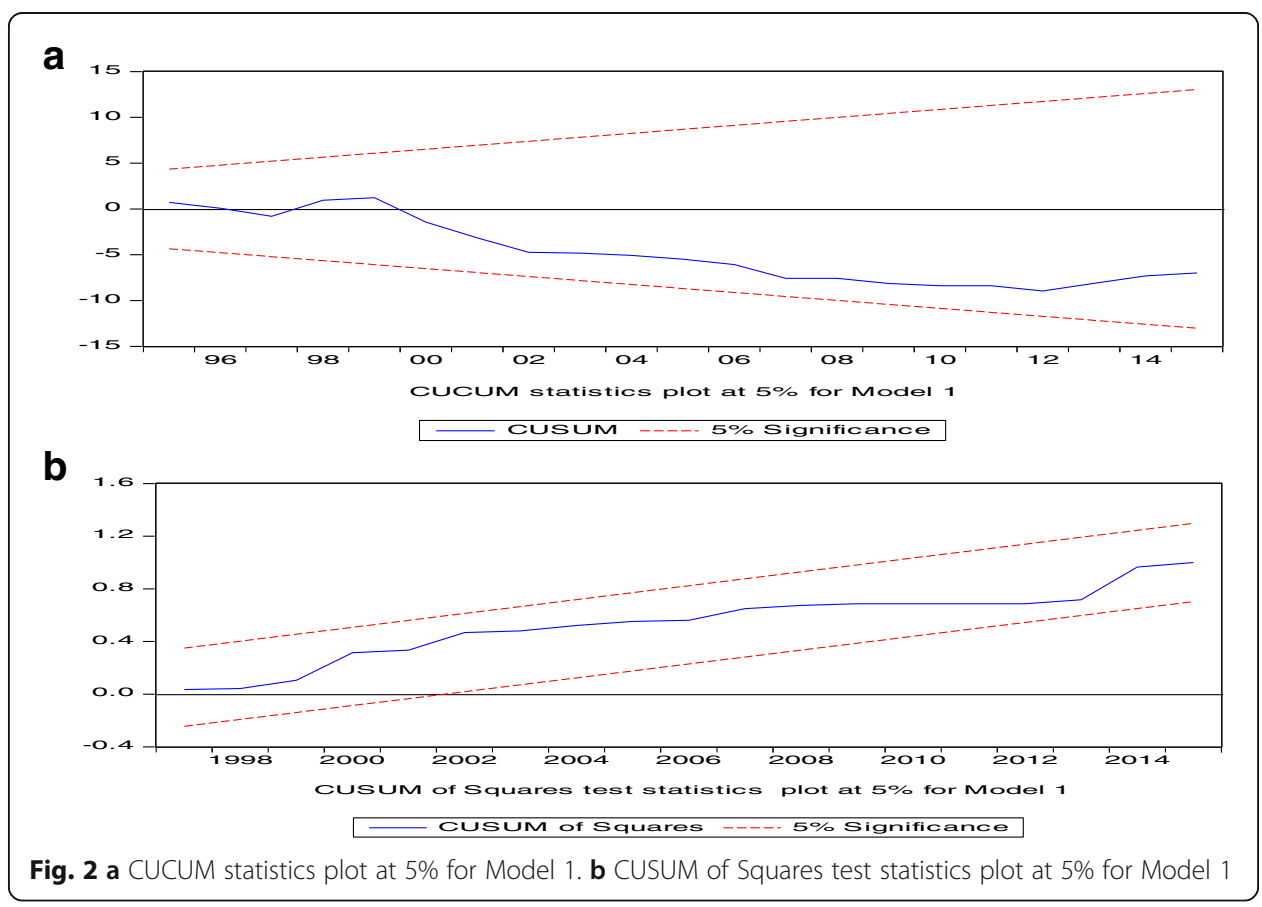




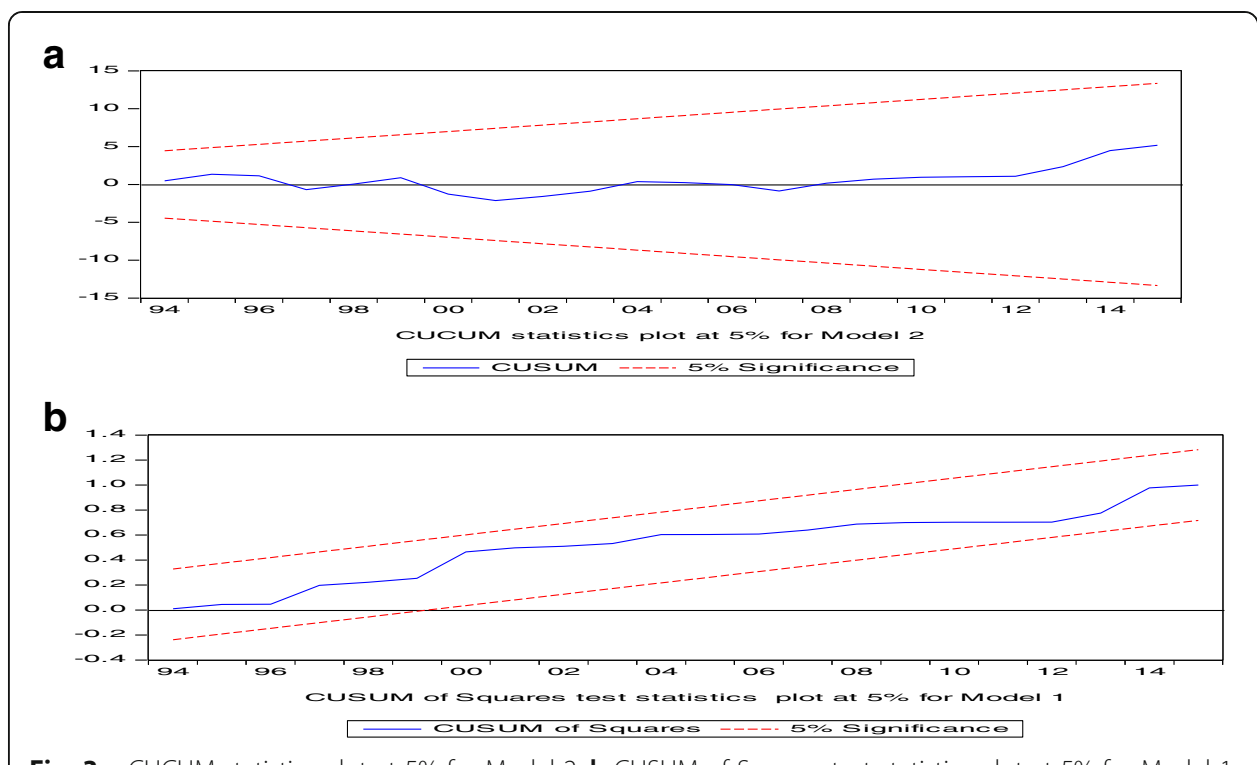

Fig. 3 a CUCUM statistics plot at 5\% for Model 2. b CUSUM of Squares test statistics plot at 5\% for Model 1

study was carried out to capture the impact of financial innovation on economic growth in Bangladesh for the period from 1980 to 2016 by applying ARDL bound testing and causality based on the ECM to capture the directional association. This study used 2 proxy variables for financial innovation (the Broad-to-Narrow Money as a percentage of the GDP (M2/M1) and Domestic Credit to Bank as a percentage of the GDP $(\mathrm{DCB})$ ) and the gross capital formation as a proxy for financial development as a percentage of the GDP.

ARDL bound testing was used to confirm the long-run cointegration between financial innovation and economic growth, and our results showed higher F-statistics for

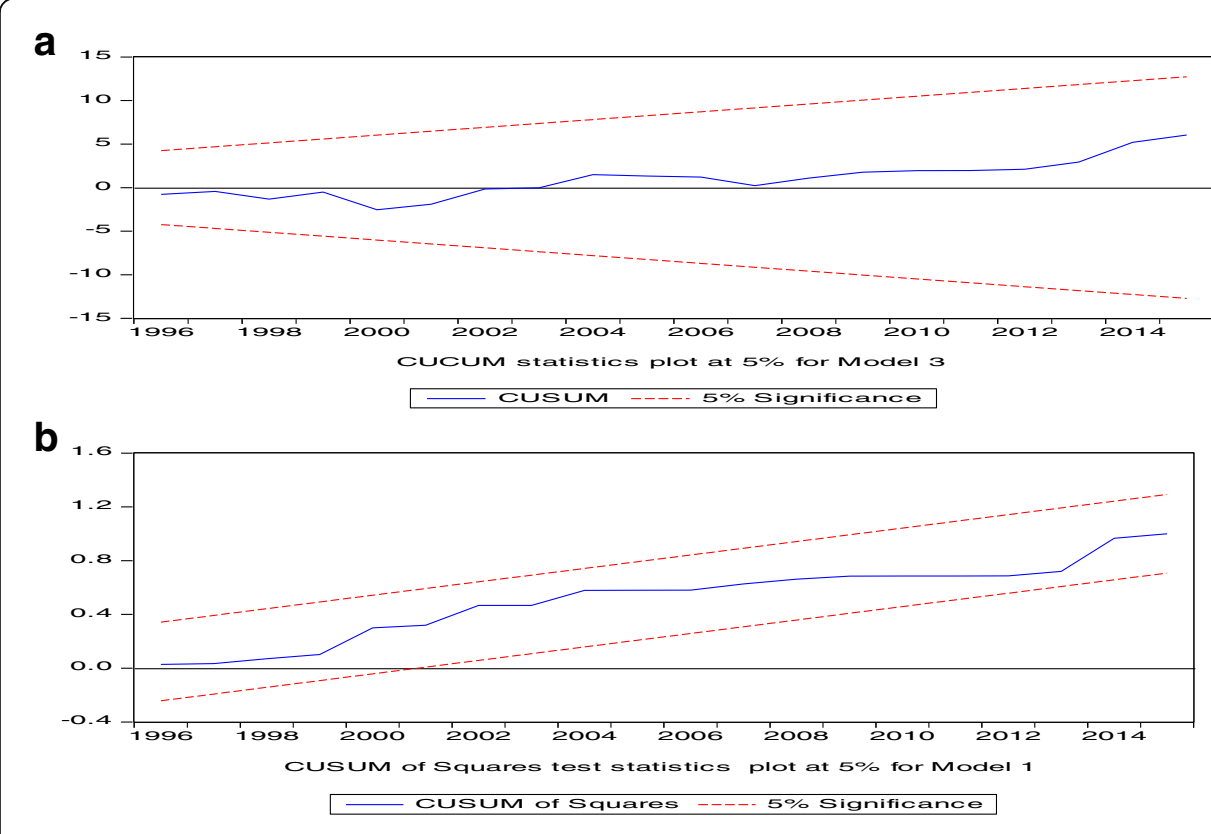

Fig. 4 a CUCUM statistics plot at 5\% for Model 3. b: CUSUM of Squares test statistics plot at 5\% for Model 1 
both proxy variables in comparison to the critical values proposed by Pesaran et al. (2001a, 2001b) and Narayan (2004). However, our results were in line with those of Mwinzi (2014), and the financial development indicator also exhibited long-run cointegration with economic growth as well. The model coefficients of each indicator of financial innovation explained their positive contribution both in the long and short run towards economic growth. The associated probability was less than 5\%, implying that it was statistically significant as well. We presumed that any initiative towards encouraging financial innovation in the financial system might have a positive influence on economic progress with efficient financial institutions, financial intermediation, and efficient allocation of economic resources; these, in turn, expedite economic growth. We also ran the Granger causality test under the ECM to capture the directional association between financial innovation and economic growth. Our study revealed the feedback causality between financial innovation and economic growth both in the long run and short run, implying that any shock either in the economic development process or financial development through encouraging financial innovation can produce positive development in the economy. Our results showed that financial innovation in the financial system can accelerate the economic growth of Bangladesh through positive improvements in financial development and the mobilization of economic resources. This is because our study found a positive and significant relationship among the M2/M1, DCB, and GGDPPC over the period from 1980 to 2016. Financial innovation, therefore, can be a source of economic growth for Bangladesh.

We recommend policymakers encourage a positive relationship between financial innovation and economic growth. First, the government should encourage a competitive financial environment with greater interactions by including both formal and informal financial institutions in the financial system. Second, the appropriate initiatives should be undertaken to merge and adopt new financial assets, services, and payment mechanisms for efficient financial development with financial innovation. Financial innovation in the economy not only causes economic growth but also promotes the financial development of the country, as well. An efficient financial system is a driver for economic growth (Ram 2007). In order to support financial innovation, the government and private sector should participate in supporting and formulating financial policy in such a way that financial innovation can be developed at its own pace.

\section{Acknowledgements}

First, of all, we would like to thank five anonymous reviews from your journal in the revision stage of submission. We also grateful to Professor Zaho from the school of economics, Wuhan University of Technology for his thoughtful suggestions and meaningful guidelines along with my fellow classmates of their opinions regarding the overall article.

Funding

We do not receive any financial assistance from any agency. All the cost associated with preparing article bear by authors solely. 


\section{Competing interests}

We, hereby, declaring that no support from any organization for the submitted work; no financial relationships with any organizations that might have an interest in the submitted work; no other relationships or activities that could appear to have influenced the submitted work.

\section{Publisher's Note}

Springer Nature remains neutral with regard to jurisdictional claims in published maps and institutional affiliations.

Received: 27 January 2017 Accepted: 29 September 2017

Published online: 10 October 2017

\section{References}

Adusei M (2013) Financial Development and Economic Growth: Evidence From Ghana. Int J Bus Financ 3(1):61-75 Ahmed AD (2006) The impact of Financial Liberalization Policies: The Case of Botswana. J Afr Dev 1(1):13-38 Ajide FM (2015) Financial Innovation and Sustainable Development in Selected Countries in West Africa. Innovation Financ 15(2):85-112

Ali MM, Hassan AFMK (2010) Dynamics of Financial Development in Cointegrated Error Correction Mechanism (ECM): Evidence from Bangladesh. Stud Bus Econ 14(2):5-24

Alimi RS (2014) Ardl Bounds Testing Approach To Cointegration: A Re-Examination Of Augmented Fisher Hypothesis In An Open Economy. Asian J Econ Model 2(2):103-114

Allen, F. (2011). Trends in Financial Innovation and Their Welfare Impact An Overview. Paper presented at the Welfare Effects of Financial Innovation, UK

Ang JB (2008) What are the mechanisms linking financial development and economic growth in Malaysia? Econ Model 15:38-53

Ansong A, Marfo-Yiadom E, Ekow-Asmah E (2011) The Effects of Financial Innovation on Financial Savings: Evidence from an Economy in Transition. J Afr Bus 12(1):93-113

Asghar N, Hussain Z (2014) Financial Development, Trade Openness and Economic Growth In Developing Countries Recent Evidence from Panel Data. Pak Econ Social Rev 52(2):99-126

Bakang MLN (2016) Effects of Financial Deepening On Economic Growth in Kenya. Int J Bus Commerce 4(7):1-50

Bangladesh Bank. (2017). SME financing report - 2017. Bangladesh Bangladesh

Bara A, Mudxingiri C (2016) Financial innovation and economic growth: evidence from Zimbabwe. Invest Manage Financ Innov 13(2):65-75

Bara A, Mugano G, Roux PL (2016) Financial Innovation and Economic Growth in the SADC. Econ Res South Afr 1(2):1-23

Battilana J, Dorado S (2010) Building sustainable hybrid organizations: The case of commercial microfinance organizations. Acad Manag J 3(2):1419-1440

BBS (2017) National Accounts Statistics - Bangladesh Bureau of Statistics Yearly. Bangladesh: Bangladesh Bureau of Statistics. pp. 250

Beck T, Chen T, Lin C, Song FM (2012) Financial Innovation: The Bright and the Dark Sides, pp 1-64

Bianchi, J., Boz, E., \& Mendoza, E. (2011). Macro-prudential Policy in a Fisherian Model of Financial Innovation. Paper presented at the 12th Jacques Polak Annual Research Conference, Washington

Bilyk, V. (2006). Financial Innovations and the Demand for Money in Ukraine: Economics Education and Research Consortium

Błach J (2011) Financial Innovations And Their Role In The Modern Financial System - Identification And Systematization Of The Problem. Financ Internet Q e-Finance 7(3):13-26

Blair MM (2011) Financial Innovation, Leverage, Bubbles And The Distribution of Income. Rev Bank Financ Law 30(1):225-311

Boot, Marinc (2010) Financial innovation: Economic growth versus instability in bank-based versus financial marketdriven economies. Int J Bus Commerce 2(1):1-32

Borensztein E, De Gregorio J, Lee J-W (1998) How does foreign direct investment affect economic growth? J Int Econ 45:115-135

Bourne C, Attzs M (2010) The role of economic Institutions in Caribbean Economic Growth and Development: from Lewis to the present. Q J Econ 15(1):1-28

Bwirea T, Musiime A (2015) Financial Development - Economic Growth Nexus: Empirical Evidence from Uganda. J Soc Sci 4(2):1-18

Cavenaile L, Gengenbach C, Palm1c F (2011) Stock Markets, Banks, and Long Run Economic Growth: A Panel Cointegration-Based Analysis. De Economist 162(1):19-40. doi:10.1007/s10645-013-9220-6.

Cheng X, Degryse H (2014) The Impact of Bank and Non-Bank Financial Institutions on Local Economic Growth in China. Journal of Financial Services Research, 37(2):179-199. doi:10.1007/s10693-009-0077-4

Chou YK (2007) Modelling Financial Innovation and Economic Growth. J Bus Manag 2(1):1-36

Chou YK, Chin MS (2011) Financial Innovations and Endogenous Growth. J Econ Manage 25(2):25-40

Comin D, Nanda R (2014) Financial Development and Technology Diffusion, vol Working Paper 15-036. Havard University, UK, p 33

Demetriades P, Hussein KA (1996) Does Financial Development Cause Economic Growth? Time Series Evidence from 16 Countries. Dev Econ 33(3):337-363

Djoumessi ECK (2009) Financial development and economic growth: a comparative study between Cameroon and South Africa. (MBA), South Africa: University Of South Africa.

Duasa J (2014) Financial Development and Economic Growth: The Experiences of Selected OIC Countries. Int J Econ Manage 8(1):215-228

Engle R, Granger C (1987) Cointegration and error correction representation: estimation and testing. Econometrica 55:251-276 Epstein SR (1992) Regional Fairs, Institutional innovaton and Economic Growth in late Medieval Europe. London School of Economics \& Political Science, United Kingdom, p 48 
Ghatak S, Siddiki JU (2001) The use of the ARDL approach in estimating virtual exchange rates in India. J Appl Stat 28(5):573-583 Glaeser EL, Porta RL, Lopez-de-Silanes F, Shleifer A (2004) Do Institutions Cause Growth? National Bureau of Economic Research, Cambridge

Habibullah MS, Yoke-Kee E (2007) Does Financial Development Cause Economic Growth? A Panel Data Dynamic Analysis for the Asian Developing Countries. J Asia Pac Econ 11(4):377-393

Handa J, Khan SR (2008) Financial development and economic growth: a symbiotic relationship. Appl Financ Econ 18:1033-1049

Hargrave, Ven VD (2006) A collective action model of institutional Innovation. Acad Manag Rev 5(1):864-888

Hye QMA, Islam F (2013) Does financial development hamper economic growth: empirical evidence from Bangladesh. J Bus Econ Manage Sci 14(3):558-582

Ilhan, O (2008) Financial Development and Economic Growth: Evidence From Turkey. Applied Econometrics and International Development 8(1),85-98.

Jedidia TB, Boujelbène T, Helalid K (2014) Financial development and economic growth: New evidence from Tunisia. J Policy Model 36(5):883-898. doi:10.1016/j.jpolmod.2014.08.002.

Johansen S (1991) Estimation and Hypothesis Testing of Cointegration Vectors in Gaussian Vector Autoregressive Models. Econometrica 59:1551-1580

Johansen-Juselius (1990) Maximum Likelihood Estimation and Inference on Cointegration - With Applications to the Demand for Money. Oxf Bull Econ Stat 51:169-210

Johnson S, Kwak J (2012) Is Financial Innovation Good For The Economy? In: Lerner J, Stern S (eds) Innovation Policy and the Economy, vol 12. USA: University of Chicago Press, pp 1-15

Kabir SH, Hoque HAAB (2007) Financial Liberalization, Financial Development and Economic Growth: Evidence from Bangladesh. Sav Dev 4(1):431-448

Kerr WR, Nanda R (2014) Financing Innovation. Harvard Business School. USA: Harvard University and NBER, p 24

Khoutem BJ, Thouraya B, \& Kamel H (2014) Financial development and economic growth: New evidence from Tunisia. Journal of Policy Modeling, 36(5), 883-898. doi:10.1016/j.jpolmod.2014.08.002.

Kotsemir M, Abroskin A (2013) Innovation Concept and Typology - An Evolutionary Discussion. Sci Technol Innov WP BRP 05/STI/2013, pp. 50

Kyophilavong P, Uddin GS, Shahbaz M (2016) The Nexus between Financial Development and Economic Growth in Lao PDR. Glob Bus Rev 17(2):303-317

Laeven L, Levine R, Michalopoulos S (2015) Financial innovation and endogenous growth. J Financ Intermed 24(1):1-24 Levine R (1997) Financial Development and Economic Growth: Views and Agenda. J Econ Lit 35(1):688-726

Lumpkin S (2010) Regulatory issues related to financial innovation. OECD J: Financ Market Trends 2:1-31

Mannah-Blankson T, Belnye F (2004) Financial innovation and the demand for money in Ghana. Bank of Ghana, Accra, pp 1-23

Masuduzzaman M (2014) Workers' Remittance Inflow, Financial Development and Economic Growth: A Study in Bangladesh. Int J Econ Financ 6(8). doi: 10.5539/ijef.v6n8p247

McGuire P \& Conroy J (2013) Fostering financial innovation for the poor The policy and regulatory environment. In: A. W. a. J. D. V. Pischke (ed) Private Finance for Human Development, USA, The Foundation for Development Cooperation

Merton RC (1992) Financial Innovation and Economic Performance. J Appl Corp Financ 4(4):12-24

Mhadhbi K (2014) Financial Development and Economic Growth: A Dynamic Panel Data Analysis. Int J Econ Financ Manage 2(2):48-58

Michael N, Ojiegbe UL, Peter O (2015) Bank And Non-Bank Financial Institutions And The Development Of The Nigerian Economy. Int J Innov Educ Res 10(2):23-36

Michalopoulos S, Laeven L, Levine R (2011) Financial Innovation and Endogenous Growth. USA: National Bureau of Economic Research, pp 1-33

Mishra PK (2010) Financial Innovation and Economic Growth -A Theoretical Approach. J Appl Corp Financ 15(1):1-6

MOF. (2016). Bangladesh Economic Review 2016: Government of the People's Republic of Bangladesh

Mosongo E, Gichana I, Ithai J, Munene N (2013) Financial Innovation and Financial Performance: A Case of SACCOs in Nairobi County. Int J Res Manage 3(5):93-100

Motsatsi JM (2016) Financial Sector Innovation and Economic Growth in the Context of Botswana. Int J Econ Financ 8(6):291-300. doi: 10.5539/ijef.v8n6p291

Mwinzi DM (2014) The Effect of Financial Innovation on Economic Growth in Kenya. (Master of Business Administration). Kenya: University of Nairobi (D61/ 60882/2013)

Nagayasu J (2012) Financial innovation and regional money. Appl Econ 44(35):4617-4629

Napier M (2014) Real Money, New Frontiers: Case Studies of Financial Innovation in Africa. Financ Innov Stud 10(2):1-10

Narayan PK (2004) Reformulating Critical Values for the Bounds F-statistics Approach to Cointegration: An Application to the Tourism Demand Model for Fiji. Monash University, Australia, pp 1-40

Narayan PK (2005) The saving and investment nexus for China: evidence from cointegration tests. Appl Econ 37(17): 1979-1990. doi:10.1080/00036840500278103

Narayan PK, Smyth R (2005) The residential demand for electricity in Australia: An application of the bounds testing approach to cointegration. Energy Policy 33(4):457-464

Ndako UB (2010) Financial Development, Economic Growth, and Stock Market Volatility: Evidence from Nigeria and South Africa. (Doctor of Philosophy), South Africa: University of Leicester.

Ndlovu G (2013) Financial Sector Development and Economic Growth: Evidence from Zimbabwe. Int J Econ Financ Issues 3(1):435-446

Nyasha S, Odhiambo NM (2016) Banks, Stock Market Development and Economic Growth in Kenya: An Empirical Investigation. J Afr Bus 18(1):1-23. doi: 10.1080/15228916.2016.1216232

Odularu GO, Okunrinboye OA (2008) Modeling the impact of financial innovation on the demand for money in Nigeria. Afr J Bus Manage 3(2):39-51

OECD. (2004). Financing Innovative SMEs in a Global Economy. Paper presented at the 2nd OECD Conference of Ministers Responsible For Small and Medium-Sized Enterprises (SMEs), Istanbul, Turkey

Ogunmuyiwa MS, Ekone AF (2010) Money supply-Economic growth nexus in Nigeria. Soc Sci J 22(3):199-204 
Omoniyi LG, Olawale AN (2015) An Application of ARDL Bounds Testing Procedure to the Estimation of Level Relationship between Exchange Rate, Crude Oil Price and Inflation Rate in Nigeria. Int J Stat Appl 5(2):81-90. doi:10.5923/j.statistics.20150502.06

Orji A, Ogbuabor JE, Anthony-Orji OI (2015) Financial Liberalization and Economic Growth in Nigeria: An Empirical Evidence. Int J Econ Financ Issues 5(3):663-672

Owusu E (2016) Stock Market and Sustainable Economic Growth in Nigeria. Economies 4(4):25. doi:10.3390/economies4040025

Ozcan YA (2008) Health Care Benchmarking and Performance Evaluation "An Assessment using Data Envelopment Analysis (DEA)". Springer, New York

Ozturk I (2008) Financial Development and Economic Growth: Evidence From Turkey. Appl Econ Int Dev 8(1):85-98

Ozturk I, Acaravci A (2010) CO2 emissions, energy consumption and economic growth in Turkey. Renew Sust Energy 14:3220-3225

Pahlavani, M., Wilson, E., \& Worthington, A. C. (2005). Trade-GDP nexus in Iran: An application of the autoregressive distributed lag (ARDL) model. Faculty of Commerce-Papers, 144

Pan L, Mishra V (2016) Stock Market Development and Economic Growth: Empirical Evidence from China. Monash University. Australia: Monash Business School, pp 1-55

Paul BP (2014a) Testing Export-Led Growth in Bangladesh: An ARDL Bounds Test Approach. Int J Trade Econ Financ 1-5. doi:10.7763/ijtef.2014.v5.331

Paul BP (2014b) Testing Export-Led Growth in Bangladesh: An ARDL Bounds Test Approach. Int J Trade Econ Financ 5(1):1-5

Pesaran MH, Shin Y, Smith JR (2001a) Bounds Testing Approaches to the Analysis of Level Relationships. J Appl Econ 16:289-326

Pesaran MH, Shin Y, Smith RJ (2001b) Bounds testing approaches to the analysis of level relationships. J Appl Econ 16(3):289-326. doi:10.1002/jae.616

Raffaelli, R., \& Glynn, M. A. (2013). Institutional Innovation: Novel, Useful, And Legitimate. Paper presented at the Institutional Analysis Conference, Harvard Business School

Rahman H (2004) Financial Development - Economic Growth Nexus: A Case Study of Bangladesh. Bangladesh Develop Stud 3(4):1-16

Ram R (2007) Financial development and economic growth: Additional evidence. J Dev Stud 35(4):164-174

Rana RH, Barua S (2015) Financial Development and Economic Growth: Evidence from a Panel Study on South Asian Countries. Asian Econ Financ Rev 5(10):1159-1173

Saad W (2014a) Financial Development and Economic Growth: Evidence from Lebanon. Int J Econ Financ 6(8):173-184

Saad W (2014b) Financial Development and Economic Growth: Evidence from Lebanon. Int J Econ Financ 6(8). doi:10.5539/ijef.v6n8p173

Sabandi M, Noviani L (2015) The Effects of Trade Liberalization, Financial Development and Economic Crisis on Economic Growth in Indonesia. J Econ Sustain Dev 6(24):120-128

Said SE, \& Dickey D (1984) Testing for Unit Roots in Autoregressive-Moving Average Models of Unknown Order. Biometrika 71(3), 599-607. doi:10.2307/2336570.

Saqib N (2015) Review Of Literature On Finance-Growth Nexus. J Appl Financ Bank 5(1):175-195

Schrieder G, Heidhues F (1995) Reaching the Poor through Financial Innovations. Q J Int Agric 2(1):132-148

Schumpeter (1911) The Theory of Economic Development. Harvard University Press, Cambridge

Schumpeter, J. (1912). Theorie der Wirtschaftlichen Entwicklung

Sekhar, G. S. (2013). Theorems and Theories of Financial Innovation: Models and Mechanism Perspective

Shahbaz M, Rehman IU, Muzaffar AT (2015) Re-Visiting Financial Development and Economic Growth Nexus: The Role of Capitalization in Bangladesh. South Afr J Econ 83(3):452-471. doi:10.1111/saje.12063

Shaughnessy, H (2015) Innovation in Financial Services: The Elastic Innovation Index Report (pp. 21): INNOTRIBE.

Shittu Al (2012) Financial Intermediation and Economic Growth in Nigeria. Br J Arts Soc Sci 4(2):164-179

Shrestha MB, Chowdhury K (2005) Ardl Modelling Approach To Testing The Financial Liberalization Hypothesis. Australia: University of Wollongong, pp 1-33

Siddiqui DA, Ahmed QM (2009) The Causal Relationship Between Institutions And Economic Growth: An Empirical Investigation For Pakistan Economy, vol MPRA Paper

Silve F, Plekhanov A (2014) Institutions, innovation, and growth: cross-country evidence. European Bank for Reconstruction and Development, London, p 28

Simiyu RS, Ndiang'ui PN, Ngugi CC (2014) Effect Of Financial Innovations And Operationalization On Market Size In Commercial Banks: A Case Study Of Equity Bank, Eldoret Branch. Int J Bus Soc Sci 85(1):227-250

Singh T (2008) Financial development and economic growth nexus: a time-series evidence from India. Appl Econ 40(12):1615-1627. doi:10.1080/00036840600892886

Sood V, Ranjan P (2015) Financial Innovation in India: An Empirical Study. J Econ Bus Rev 10(1):1-20

Štreimikiene, D. (2014). World economic forum 2012

Sunde T (2013) Financial Development And Economic Growth: Empirical Evidence From Namibia. J Emerg Issues Econ Financ Bank 10(1):52-65

Tyavambiza T, Nyangara D (2015) Financial and Monetary Reforms and the Finance-Growth Relationship in Zimbabwe. Int J Econ Financ Issues 5(2):590-602

Uddin GS, Kyophilavong P, Sydee N (2012) The Casual Nexus of Banking Sector Development and Poverty Reduction in Bangladesh. Int J Econ Financ Issues 2(3):304-311

Uddin GS, Shahbaz M, Arouri M, Teulon F (2014b) Financial development and poverty reduction nexus: A cointegration and causality analysis in Bangladesh. Econ Model 36:405-412. doi:10.1016/j.econmod.2013.09.049

Uddin KMK, Rahman MM, Quaosar GMAA (2014a) Causality between Exchange Rate and Economic Growth in Bangladesh. Eur Sci J 10(31):11-26

Uddin, M. G. S., \& Chakraborty, L. (2014). International Trade, Financial Development and Economic Growth Nexus in Bangladesh: Empirical Evidence from Time Series Approach

Valverde CS, Del Paso RL, Fernández FR (2007) Financial innovations in banking: Impact on regional growth. Reg Stud 41(3):311-326 
Wachter JA (2006) Comment on: "Can financial innovation help to explain the reduced volatility of economic activity?". $J$ Monet Econ 53:151-154

Wadud M a (2009) Financial development and economic growth: a cointegration and error correction modeling approach for south Asian countries. Econ Bull 29(3):1670-1677

World Bank. (2017). World Development Indicators. 2017, From: http//data.worldbank.org/data-catalog/world-development-indicators World Economic Outlook. (2017). World Economic Outlook (WEO) data, IMF 2017

Submit your manuscript to a SpringerOpen ${ }^{0}$ journal and benefit from:

- Convenient online submission

- Rigorous peer review

- Open access: articles freely available online

- High visibility within the field

- Retaining the copyright to your article

Submit your next manuscript at $>$ springeropen.com 